\title{
Technical Note: A new global database of trace gases and aerosols from multiple sources of high vertical resolution measurements
}

\author{
B. Hassler ${ }^{1,2}$, G. E. Bodeker ${ }^{2}$, and M. Dameris ${ }^{3}$ \\ ${ }^{1}$ Meteorological Institute, University of Munich, Munich, Germany \\ ${ }^{2}$ National Institute of Water and Atmospheric Research, Lauder, New Zealand \\ ${ }^{3}$ Deutsches Zentrum für Luft- und Raumfahrt, Institut für Physik der Atmosphäre, Oberpfaffenhofen, Germany \\ Received: 20 February 2008 - Published in Atmos. Chem. Phys. Discuss.: 18 April 2008 \\ Revised: 22 July 2008 - Accepted: 14 August 2008 - Published: 10 September 2008
}

\begin{abstract}
A new database of trace gases and aerosols with global coverage, derived from high vertical resolution profile measurements, has been assembled as a collection of binary data files; hereafter referred to as the "Binary DataBase of Profiles" (BDBP). Version 1.0 of the BDBP, described here, includes measurements from different satellite- (HALOE, POAM II and III, SAGE I and II) and ground-based measurement systems (ozonesondes). In addition to the primary product of ozone, secondary measurements of other trace gases, aerosol extinction, and temperature are included. All data are subjected to very strict quality control and for every measurement a percentage error on the measurement is included. To facilitate analyses, each measurement is added to 3 different instances ( 3 different grids) of the database where measurements are indexed by: (1) geographic latitude, longitude, altitude (in $1 \mathrm{~km}$ steps) and time, (2) geographic latitude, longitude, pressure (at levels $\sim 1 \mathrm{~km}$ apart) and time, (3) equivalent latitude, potential temperature ( 8 levels from $300 \mathrm{~K}$ to $650 \mathrm{~K}$ ) and time.

In contrast to existing zonal mean databases, by including a wider range of measurement sources (both satellite and ozonesondes), the BDBP is sufficiently dense to permit calculation of changes in ozone by latitude, longitude and altitude. In addition, by including other trace gases such as water vapour, this database can be used for comprehensive radiative transfer calculations. By providing the original measurements rather than derived monthly means, the BDBP is applicable to a wider range of applications than databases containing only monthly mean data. Monthly mean zonal mean ozone concentrations calculated from the BDBP are compared with the database of Randel and $\mathrm{Wu}$, which has been
\end{abstract}

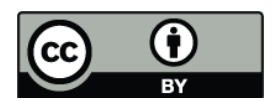

Correspondence to: B. Hassler (b.hassler@niwa.co.nz) used in many earlier analyses. As opposed to that database which is generated from regression model fits, the BDBP uses the original (quality controlled) measurements with no smoothing applied in any way and as a result displays higher natural variability.

\section{Introduction}

Ozone is a greenhouse gas and as such past and future changes in ozone drive changes in radiative forcing of the climate system. To incorporate these changes in radiative forcing by ozone, global climate models require ozone boundary conditions that span the atmosphere from the surface to the lower mesosphere $(0-70 \mathrm{~km})$, from pole to pole, and at high vertical resolution e.g. to resolve changes in ozone close to the tropopause where the effect on radiative forcing is largest (Forster and Shine, 1997). Furthermore, if zonal asymmetries in the ozone changes can be included, this results in a more accurate representation of changes in radiative forcing.

A vertically resolved ozone database with sufficient density to detect changes in ozone as a function of latitude, longitude and altitude, is valuable for attributing past changes in ozone e.g. zonal asymmetry in ozone trends may be indicative of the influence of changes in dynamics. Such a database is also valuable for the evaluation of chemistry-climate models and in particular for validating the ability of these models to reproduce the latitude-altitude structure in past ozone changes. The BDBP has the necessary structure, data coverage and data quality to be of use for the outlined applications. That said, this version of the BDBP is unlikely to be suitable for trend analysis as it stands since offsets and drifts between the different sources of data could induce false trends. A

Published by Copernicus Publications on behalf of the European Geosciences Union. 
brief discussion of how future versions of the BDBP will resolve this issue is presented in Sect. 6.

There are two commonly used vertical ozone profile databases currently available (Fortuin and Kelder, 1998; Randel and $\mathrm{Wu}, 2007)$. However, both report monthly mean zonal mean data only, with no longitudinal resolution. The BDBP is not a zonal mean database and individual measurement sets are archived. A measurement set is a group of measurements made at the same date, time, latitude, longitude, altitude and from the same instrument. As a result, the BDBP can be used to extract ozone profiles for a specified location.

In Randel and Wu (2007) no changes in tropospheric ozone are reported and ozonesondes are used only from Syowa and Resolute. These ozonesonde measurements are used to infer changes in ozone poleward of $60^{\circ}$ latitude. Because Syowa $\left(69^{\circ} \mathrm{S}\right)$ is close to the Antarctic vortex edge, meridional movements of the vortex result in Syowa ozonesondes sampling air from both inside and outside the vortex and therefore decreases in ozone over the Antarctic are likely underestimated.

Fortuin and Kelder (1998) built their database using ozonesonde profiles from selected stations and SBUVSBUV/2 measurements from 1980 to 1991, mainly to provide an ozone climatology for global climate model simulations. For the BDBP many more ozonesonde stations were available providing a greater degree of coverage. Furthermore, longer periods of data were available for the ozonesonde stations, and therefore a considerably longer time period for this database could be achieved. In addition, the high vertical resolution of the BDBP allows more detailed analyses of vertical ozone structures compared to the 19 pressure levels in the Fortuin and Kelder database.

The BDBP has been implemented in a flexible and extensible data file format structured for rapid extraction of data. Three different instances of the database have been created where measurements are indexed by: (1) geographic latitude, longitude, altitude (in $1 \mathrm{~km}$ steps) and time, (2) geographic latitude, longitude, pressure (at levels $\sim 1 \mathrm{~km}$ apart) and time, (3) equivalent latitude (Butchart and Remsberg, 1986), potential temperature (8 levels from $300 \mathrm{~K}$ to $650 \mathrm{~K}$ ) and time (see Sect. 2). A detailed description of the different data sources from which measurements have been added to Version 1 of the BDBP is given in Sect. 3. By including data from as many sources as possible, dense coverage of the globe, at high temporal resolution, is achieved. The spatial and temporal coverage of the database is quantified in Sect. 4. Monthly mean $2^{\circ}$ zonal mean ozone concentrations were extracted from the BDBP and are compared with the data set of Randel and Wu (2007) in Sect. 5. Section 6 then shows some examples from the BDBP of $\mathrm{O}_{3}, \mathrm{NO}_{2}$ and $\mathrm{H}_{2} \mathrm{O}$ for one (or more) specified level(s) and a defined latitude region. Finally, in Sect. 6, the advantages of the BDBP over other existing databases are highlighted and suggestions are made for possible applications of the BDBP.

\section{Database structure}

To facilitate analysis of the BDBP, three different instances of the database were assembled, each comprising a 3dimensional data grid (Fig. 1).

In all cases one of the dimensions is time. The other two dimensions are: in Grid I, geographical latitude and altitude, in Grid II, geographical latitude and pressure, and in Grid III, equivalent latitude and potential temperature. The data are stored within the grids as "measurement sets". A measurement set is a collection of measurements made at the same date and time, latitude, longitude, and altitude, from the same instrument, which are stored together with the source of the measurement set (e.g. "SAGE2 V6.2"). Each grid contains the same source data but gridded in three different ways to provide different meridional slices of the database. For example, in Grid III, binning the data by equivalent latitude and potential temperature preserves the steep meridional gradients in any zonal means calculated from the database, e.g. close to the vortex edge. In the other two grids these would be smeared out as a consequence of averaging data inside and outside the vortex on lines of constant latitude. For each grid, the data are stored in 90 files, each of which span $2^{\circ}$ in geographic latitude or, for Grid III, $2^{\circ}$ of equivalent latitude, for convenience. Grid I has 70 altitude levels extending from $1 \mathrm{~km}$ to $70 \mathrm{~km}$ in $1 \mathrm{~km}$ steps, and the measurements have been interpolated to these levels (as discussed further below).

The altitude grid is a geopotential height grid and when the original data are provided in geometric altitude (SAGE I, SAGE II, POAM II and POAM III) the geometric altitudes are converted to geopotential heights.

Grid II has 70 pressure levels spaced approximately $1 \mathrm{~km}$ apart given by:

$p_{n}=p_{0} e^{-n / 7}, n=1 . .70$

where $p_{0}=1013.25 \mathrm{hPa}$.

The pressure levels are exactly $1 \mathrm{~km}$ apart when the scale height $(\mathrm{RT} / \mathrm{g})$ is $7 \mathrm{~km}\left(R=286.9 \mathrm{~N} \mathrm{~m} \mathrm{~kg}^{-1} \mathrm{~K}^{-1}, g=9.8 \mathrm{~m} \mathrm{~s}^{-1}\right)$. Grid III has 8 potential temperature levels at $300,315,330$, $350,400,450,550$, and $650 \mathrm{~K}$ matching the standard output levels of the NCEP/NCAR potential temperature database (http://dss.ucar.edu/datasets/ds090.0/). The lowest levels of 270,280 , and $290 \mathrm{~K}$ were excluded because these levels intersect the Earth's surface and confound the calculation of equivalent latitude. Meridional profiles of potential vorticity (PV) by equivalent latitude (see Fig. 1 a of Nash et al., 1996) were calculated from NCEP/NCAR reanalyses (Kistler et al., 2001) every 6 hours on the 8 isentropic levels listed above. The equivalent latitude for a given measurement set on a given isentropic level is calculated by taking the PV at the measurement latitude and longitude, and, using the meridional profile of PV vs. equivalent latitude at the nearest $6 \mathrm{~h}$ mark, the equivalent latitude is linearly interpolated using the PV value. Grid III in version 1.0 of the BDBP has no data 


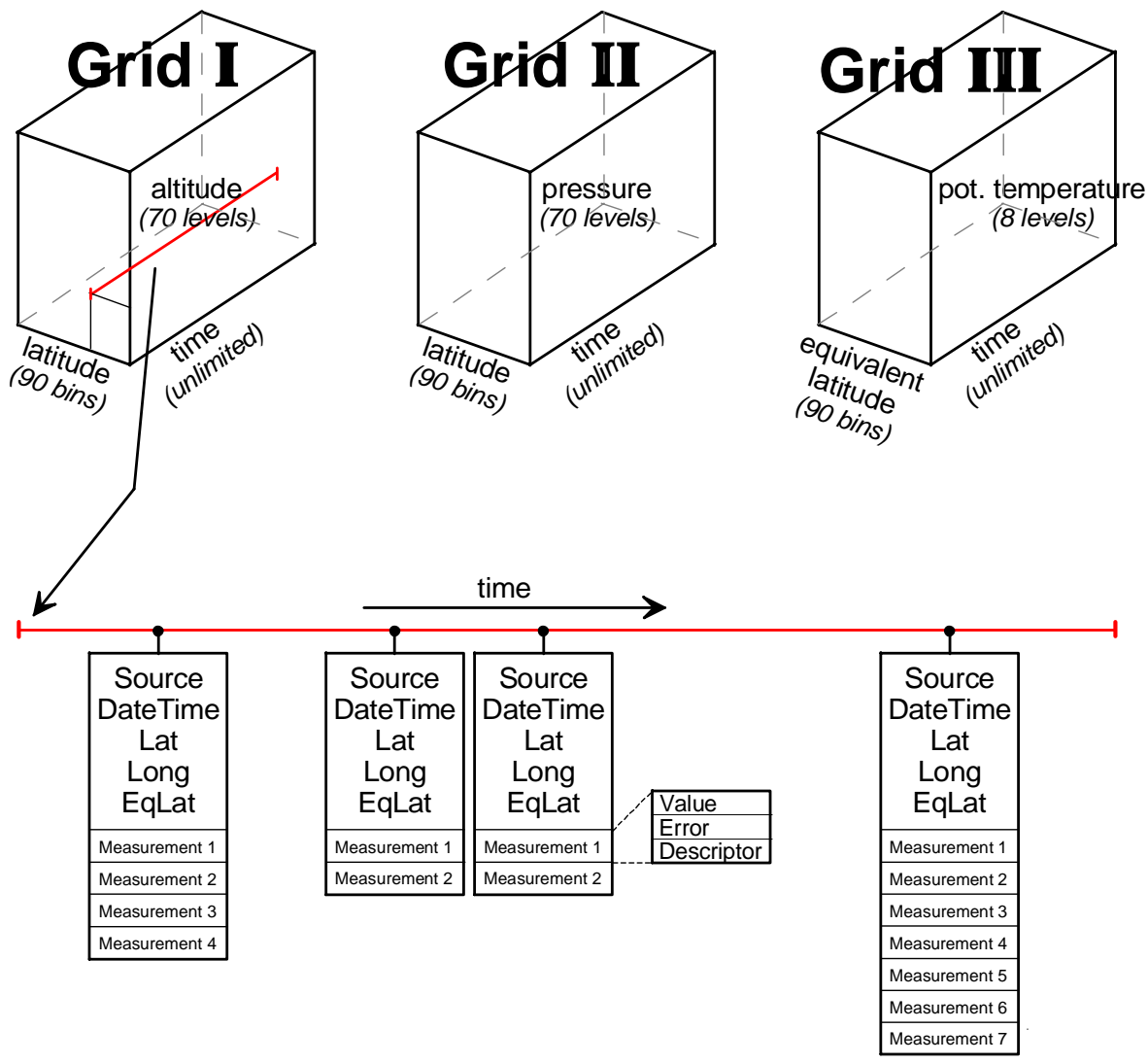

Fig. 1. Schematic overview of the database structure. For all three database grids there are 90 latitude bins. The number of altitude levels changes for the different database grids: Grid I and II have 70 levels while Grid III has 8 levels.

before 1978 since equivalent latitudes before 1978 were not available.

Each measurement comprises a value, an error in percent, and a data descriptor (e.g. "Ozone"). The length of each measurement set varies according to the number of measurements available. In this way, the grids are kept compact since no null values need to be stored. If the source data are in the form of vertical profiles, values are interpolated onto the pre-defined vertical levels with the result that the profile is no longer kept as a single entity within the grid. Each measurement set has its own unique time stamp and therefore the measurement sets at a given altitude and latitude bin need not be equally spaced in time (see Fig. 1).

The primary target variable for this version of the BDBP is ozone and the data sources used have been selected to optimise the spatial and temporal coverage for this variable. Where other coincident measurements (e.g. $\mathrm{NO}_{2}$ or $\mathrm{H}_{2} \mathrm{O}$ ) are available from the data sources, these have been added to the grids. The variables included in the BDBP, together with their data sources, are listed in Table 1. Two different types of ozone are provided, namely high resolution ozone and low resolution ozone. The high resolution ozone comes from the ozonesondes only. The low resolution ozone is deduced from the satellite based measurements and are derived from the ozonesonde profiles after a 1500 m FWHM Gaussian filter has been applied. The width of the Gaussian filter was selected based on comparisons between smoothed ozonesonde profiles and SAGE II profiles. By providing both high and low resolution ozone data from the ozonesondes comparisons between ozonesondes and satellite based measurements are facilitated.

Version 1 of the BDBP is made freely available at http: //www.niwa.co.nz/rc/atmos/bdbp. This webpage includes additional technical details, information how to download the database, and how to extract data from the files. All three grids of the database comprise $\sim 3 \mathrm{~Gb}$. The database files have been designed to be platform independent and reading routines in a number of programming languages are provided on the webpage. 
Table 1. Variables stored in version 1.0 of the BDBP, together with their units and data source(s).

\begin{tabular}{|c|c|c|}
\hline Species & Unit & Data sources \\
\hline $\mathrm{O}_{3}$ number density (high res.) & $10^{18}$ molecules $/ \mathrm{m}^{3}$ & ozonesondes \\
\hline $\mathrm{O}_{3}$ number density (low res.) & $10^{18}$ molecules $/ \mathrm{m}^{3}$ & SAGE I+II, POAM II+III, HALOE, ozonesondes \\
\hline Temperature $^{\mathrm{a}}$ & $\mathrm{K}$ & SAGE I+II, POAM II+III, HALOE, ozonesondes \\
\hline $\mathrm{NO}_{2}$ number density & $10^{18}$ molecules $/ \mathrm{m}^{3}$ & SAGE I+II, POAM II+III, HALOE \\
\hline $\mathrm{H}_{2} \mathrm{O}$ mixing ratio & $10^{-6}$ moles $/$ mole & SAGE II, POAM II+III, HALOE \\
\hline NO mixing ratio & $10^{-9}$ moles $/$ mole & HALOE \\
\hline $\mathrm{CH}_{4}$ mixing ratio & $10^{-6}$ moles $/$ mole & HALOE \\
\hline $\mathrm{HCl}$ mixing ratio & $10^{-9}$ moles $/$ mole & HALOE \\
\hline HF mixing ratio & $10^{-9}$ moles $/$ mole & HALOE \\
\hline Relative humidity & $\%$ & ozonesondes \\
\hline Aerosol extinction at $352.3 \mathrm{~nm}$ & $1 / \mathrm{km}$ & POAM II \\
\hline Aerosol extinction at $353.4 \mathrm{~nm}$ & $1 / \mathrm{km}$ & POAM III \\
\hline Aerosol extinction at $385 \mathrm{~nm}$ & $1 / \mathrm{km}$ & SAGE II \\
\hline Aerosol extinction at $441.6 \mathrm{~nm}$ & $1 / \mathrm{km}$ & POAM II \\
\hline Aerosol extinction at $442.3 \mathrm{~nm}$ & $1 / \mathrm{km}$ & POAM III \\
\hline Aerosol extinction at $450 \mathrm{~nm}$ & $1 / \mathrm{km}$ & SAGE I \\
\hline Aerosol extinction at $453 \mathrm{~nm}$ & $1 / \mathrm{km}$ & SAGE II \\
\hline Aerosol extinction at $525 \mathrm{~nm}$ & $1 / \mathrm{km}$ & SAGE II \\
\hline Aerosol extinction at $601.4 \mathrm{~nm}$ & $1 / \mathrm{km}$ & POAM II \\
\hline Aerosol extinction at $603.4 \mathrm{~nm}$ & $1 / \mathrm{km}$ & POAM III \\
\hline Aerosol extinction at $779.4 \mathrm{~nm}$ & $1 / \mathrm{km}$ & POAM III \\
\hline Aerosol extinction at $781 \mathrm{~nm}$ & $1 / \mathrm{km}$ & POAM II \\
\hline Aerosol extinction at $921 \mathrm{~nm}$ & $1 / \mathrm{km}$ & POAM II \\
\hline Aerosol extinction at $922.4 \mathrm{~nm}$ & $1 / \mathrm{km}$ & POAM III \\
\hline Aerosol extinction at $1000 \mathrm{~nm}$ & $1 / \mathrm{km}$ & SAGE I \\
\hline Aerosol extinction at $1018 \mathrm{~nm}$ & $1 / \mathrm{km}$ & POAM III \\
\hline Aerosol extinction at $1020 \mathrm{~nm}$ & $1 / \mathrm{km}$ & SAGE II \\
\hline Aerosol extinction at $1060 \mathrm{~nm}$ & $1 / \mathrm{km}$ & POAM II \\
\hline Aerosol surface area density & $\mu \mathrm{m}^{2} / \mathrm{cm}^{3}$ & SAGE II \\
\hline Aerosol effective radius & $\mu \mathrm{m}$ & SAGE II \\
\hline
\end{tabular}

a only measured for ozonesondes; for other sources it is extracted from reanalyses

\section{Data sources}

Criteria for the selection of source data for this version of the BDBP were:

1. Only profile data are considered and only profiles with high vertical resolution (i.e. better than $\sim 1.5 \mathrm{~km}$ ). Two data sources fulfilling these criteria are solar occultation satellite-based instruments and ozonesondes. Lidar and aircraft profile measurements would also have been suitable but were not included in this version of the BDBP since we required coincident temperature and/or pressure data to permit the data to be included in Grids II and III and these were not always available. Furthermore, these data sources would not have added significant quantities of data to the BDBP.
2. All measurements must include an indication of measurement precision and the measurement errors should preferably be small.

3. Source data spanning longer periods were given higher priority.

4. Measurements covering a data sparse region of the globe were given high priority.

These criteria led to the use of HALOE, SAGE I, SAGE II, POAM II, POAM III and ozonesondes as data sources for this version of the BDBP. The specifics concerning the addition of each of these data sources are given in Sects. 3.1 to 3.4 . 


\subsection{SAGE I and II}

\subsubsection{SAGE I and II instrument and data information}

Both Stratospheric Aerosol and Gas Experiment (SAGE) instruments were built and launched by NASA (see for example McCormick et al., 1989; Cunnold et al., 1989; Nazaryan and McCormick, 2005; Liu et al., 2006). Version 6.1 SAGE I data were provided by L. W. Thomason (NASA; personal communication, 2007). The SAGE I measurements start in February 1979 and stop in November 1981 spanning $79^{\circ} \mathrm{S}$ to $79^{\circ} \mathrm{N}$.

Version 6.2 SAGE II data were used (Wang et al., 2006, http://eosweb.larc.nasa.gov/project/sage2/table_sage2. html') which started in October 1984 and ended in August 2005. The spatial coverage spans $80^{\circ} \mathrm{S}$ to $80^{\circ} \mathrm{N}$ (see Table 2), although coverage can be sparse at higher latitudes in winter (Wang et al., 2002).

Measurement errors for SAGE I and SAGE II, included in the BDBP, are given in the source data files and are calculated by accounting for all known sources of uncertainty in the measurement. For both SAGE I and II the temperature and pressure values included in the data files were not retrieved parameters, but were provided by the National Meteorological Center (NMC). Nevertheless they were used to determine the levels at which the data were inserted into Grid II and Grid III, and were also included as measurements within each measurement set.

Since both SAGE I and SAGE II measure trace gas profiles with the solar occultation method, an additional identifier specifying whether the measurement was made at sunrise or sunset was included in each SAGE measurement set.

\subsubsection{Altitude correction for SAGE I data}

There is a known altitude error in SAGE I observations (Veiga et al., 1995). Wang et al. (1996) discuss and analyse this error in detail. To correct for this error in the SAGE I data, an altitude correction based on Fig. 3 of Wang et al. (1996) was performed. Altitudes for every profile measured between $60^{\circ} \mathrm{N}$ and $60^{\circ} \mathrm{S}$ were shifted upwards by an offset dependent on latitude but independent on altitude i.e. the measured profiles are shifted rigidly upwards. Although Wang et al. (1996) only discuss the altitude error for ozone profiles, the correction was applied to all measurements. Pressure and temperature values were assumed to be correct since they were provided from NMC directly (Wang et al., 1996) and therefore the pressure profiles were not shifted.

\subsubsection{Screening of SAGE I data}

There are few publications, if any, that describe how best to screen SAGE I data to remove outliers. Therefore, in this analysis, data quality controls, similar to those performed for the SAGE II data (described below), were applied to remove outliers from the $\mathrm{O}_{3}$ and $\mathrm{NO}_{2}$ data. Particularly be- low $15 \mathrm{~km}$, measurements of $\mathrm{O}_{3}$ and $\mathrm{NO}_{2}$ can be affected by aerosols. Therefore, measurements of $\mathrm{O}_{3}$ and $\mathrm{NO}_{2}$ were removed if the aerosol extinction at $1000 \mathrm{~nm}$ was higher than $0.001 / \mathrm{km}$ (L. W. Thomason, NASA, personal communication, 2007). Nevertheless, the utility of the SAGE I data below $15 \mathrm{~km}$ is limited to qualitative rather than quantitative analyses (e.g. looking for geographical regions of enhanced upper tropospheric ozone). These data are retained in the BDBP with their high error values to allow later screening.

\subsubsection{Screening of SAGE II data}

Rind et al. (2005) showed that $\mathrm{O}_{3}, \mathrm{NO}_{2}$ and $\mathrm{H}_{2} \mathrm{O}$ measurements from SAGE II are affected by interference from aerosols and clouds. Since the original SAGE II data are only available in an unscreened version (although they are provided with quality flags for unreliable data) additional treatment of the data was necessary to ensure the highest possible quality. The screening was performed following the suggestions of Wang et al. (1996) and Rind et al. (2005). Data points or whole profiles were removed if the following checks were true:

For $\mathrm{O}_{3}$ specifically:

- From the time when the beta angle of the spacecraft (the angle between the satellite orbit plane and the Earth to Sun vector) exceeds $60^{\circ}$ until it returns to less than $40^{\circ}$ all profiles are excluded.

- All measurements below $23 \mathrm{~km}$ from July 1991 to October 1993 are excluded to avoid the confounding effects of the Mt. Pinatubo eruption.

- Measurements between 23 June 1993 and 11 April 1994 , between $30 \mathrm{~km}$ and $50 \mathrm{~km}$ are excluded whenever the quoted measurement error exceeds $10 \%$.

- Measurements between $10.5 \mathrm{~km}$ and $24.5 \mathrm{~km}$ are excluded if the ozone mixing ratio exceeds $10 \mathrm{ppm}$.

- Measurements above $25 \mathrm{~km}$ are excluded if values are $>100 \mathrm{ppm}$.

- Measurements at altitudes above $3 \mathrm{hPa}$ are excluded if values are $>50 \mathrm{ppm}$.

- Measurements in the mid- to upper troposphere are excluded when clouds are present as denoted by the cloud quality flags in the data files.

For $\mathrm{NO}_{2}$ specifically:

- If the $1020 \mathrm{~nm}$ aerosol absorption is greater than $7 \times 10^{-4} \mathrm{~km}^{-1}$ the measurement is excluded. 
Table 2. Coverage, vertical resolution, period spanned and source of the data for the satellite-based measurements included in version 1.0 of the BDBP.

\begin{tabular}{lcccr}
\hline Instrument & Latitudinal coverage & Vertical resolution & Period spanned & Data Source \\
\hline HALOE & $80^{\circ} \mathrm{S}-80^{\circ} \mathrm{N}$ & $\sim 1.6 \mathrm{~km}$ & $10 / 1991-11 / 2005$ & NASA \\
POAM II & $88^{\circ} \mathrm{S}-63^{\circ} \mathrm{S}, 55^{\circ} \mathrm{N}-71^{\circ} \mathrm{N}$ & $\sim 1 \mathrm{~km}$ & $10 / 1993-11 / 1996$ & NRL \\
POAM III & $88^{\circ} \mathrm{S}-62^{\circ} \mathrm{S}, 54^{\circ} \mathrm{N}-71^{\circ} \mathrm{N}$ & $\sim 1 \mathrm{~km}$ & $04 / 1998-11 / 2005$ & NRL \\
SAGE I & $79^{\circ} \mathrm{S}-79^{\circ} \mathrm{N}$ & $\sim 1 \mathrm{~km}$ & $02 / 1979-11 / 1981$ & NASA \\
& & & & personal communication, 2007) \\
SAGE II & $80^{\circ} \mathrm{S}-80^{\circ} \mathrm{N}$ & $\sim 1 \mathrm{~km}$ & $10 / 1984-08 / 2005$ & NASA \\
\hline
\end{tabular}

For $\mathrm{H}_{2} \mathrm{O}$ specifically:

- If the relative humidity exceeds $100 \%$ or is less than $0 \%$ the measurement is excluded.

- If clouds are present anywhere between 6 and $25.5 \mathrm{~km}$ (as denoted by the cloud identifier flags) the water vapour measurement at the altitude of the flagged clouds is omitted.

- Above the tropopause, if the aerosol absorption at $1020 \mathrm{~nm}$ exceeds $4 \times 10^{-4} \mathrm{~km}^{-1}$ the water vapour measurement is excluded.

- If the optical depth at $1020 \mathrm{~nm}$ is large (as denoted by the quality flags) the measurement is excluded.

- If the $\mathrm{H}_{2} \mathrm{O}$ slow convergence flag is set, the measurement is excluded.

For all aerosol extinction measurements:

- If the "T-C inversion routine failure for the screened aerosol extinction retrieval" is set, the measurement is excluded.

- If the "cloud test not successful" flag is set, the measurement is excluded.

Furthermore:

- For $\mathrm{NO}_{2}$ and $\mathrm{H}_{2} \mathrm{O}$, all measurements between 23 June 1993 and 10 April 1994, at altitudes above $30 \mathrm{hPa}$ are excluded.

- For $\mathrm{NO}_{2}$ and $\mathrm{H}_{2} \mathrm{O}$, all measurements in November 1991, September 1992 and October 1992 at altitude below $150 \mathrm{hPa}$ are excluded.

- For $\mathrm{O}_{3}$ and $\mathrm{H}_{2} \mathrm{O}$, all measurements in the first $6 \mathrm{~km}$ are removed when there is large absorption (integrated value above that level bigger than about 5\%) in the $1020 \mathrm{~nm}$ channel (Rind et al., 2005).

- For $\mathrm{O}_{3}, \mathrm{NO}_{2}$ and $\mathrm{H}_{2} \mathrm{O}$, if the measurement is more than $10 \sigma$ away from the monthly mean value for that latitude ( $15^{\circ}$ zones), longitude $\left(90^{\circ}\right.$ quadrants) and altitude $(0.5 \mathrm{~km}$ grid), the measurement is excluded.
The climatology and statistics needed to perform the last test were calculated separately for each of the 3 species as area weighted means from the unscreened SAGE II data.

\subsection{HALOE}

The Halogen Occultation Experiment (HALOE) was launched in September 1991 as a NASA project. Measurements are available from October 1991 until November 2005 in the latest Version 19. HALOE uses solar occultation to simultaneously measure, amongst others, vertical profiles of $\mathrm{O}_{3}, \mathrm{HCl}, \mathrm{HF}, \mathrm{CH}_{4}, \mathrm{H}_{2} \mathrm{O}, \mathrm{NO}$ and $\mathrm{NO}_{2}$ which are added to the BDBP. Temperature and pressure profiles above $35 \mathrm{~km}$ are retrieved from measurements whereas below $35 \mathrm{~km}$ NCEP fields are used (SPARC, 1998). Nevertheless, pressure as well as temperature were used to determine the levels at which the data were inserted into Grid II and Grid III, and were also included as measurements within each measurement set. The altitude range of the measurements extends from $\sim 15 \mathrm{~km}$ to $60-130 \mathrm{~km}$, depending on the species (see Tab. 3). Although the vertical resolution of the profiles is $\sim 1.6 \mathrm{~km}$, the data were included in the BDBP since these measurements provide good global coverage and have been used in numerous previous studies (McKenna et al., 2002; Steil et al., 2003; Remsberg and Deaver, 2005). For every measurement a measurement error is also provided in the source data files and these are added to the BDBP. A sunrise/sunset identifier is also included in each measurement set. HALOE data are already screened for cirrus cloud contamination, described in Hervig and McHugh (1999), and therefore no additional screening of the data was done. A detailed analysis of the HALOE ozone data quality (Version 18) is presented in Bhatt et al. (1999). For a more detailed HALOE data description see Russell et al. (1993).

\subsection{POAM II and III}

The Polar Ozone and Aerosol Measurement II (POAM II) instrument was developed by the Naval Research Laboratory (NRL) to measure the vertical distribution of atmospheric $\mathrm{O}_{3}, \mathrm{H}_{2} \mathrm{O}, \mathrm{NO}_{2}$, aerosol extinction, and temperature. It covers a spectral range from approximately 350 to $1060 \mathrm{~nm}$ in nine 
Table 3. Altitude range of the satellite-based measurements incorporated in version 1.0 of the BDBP.

\begin{tabular}{lccccr}
\hline Variable & HALOE & POAM II & POAM III & SAGE I & SAGE II \\
\hline $\mathrm{O}_{3}$ & $10-90 \mathrm{~km}$ & $15-50 \mathrm{~km}$ & $5-60 \mathrm{~km}$ & $10-70 \mathrm{~km}$ & $5-60 \mathrm{~km}$ \\
$\mathrm{NO}_{2}$ & $15-55 \mathrm{~km}$ & $20-40 \mathrm{~km}$ & $20-40 \mathrm{~km}$ & $10-70 \mathrm{~km}$ & $15-60 \mathrm{~km}$ \\
$\mathrm{H}_{2} \mathrm{O}$ & $10-80 \mathrm{~km}$ & - & $5-45 \mathrm{~km}$ & - & $10-40 \mathrm{~km}$ \\
Aerosols & $15-50 \mathrm{~km}$ & $10-30 \mathrm{~km}$ & $5-25 \mathrm{~km}$ & $10-40.5 \mathrm{~km}$ & $1-45 \mathrm{~km}$ \\
$\mathrm{HCl}$ & $15-60 \mathrm{~km}$ & - & - & - & - \\
$\mathrm{HF}$ & $15-60 \mathrm{~km}$ & - & - & - & - \\
$\mathrm{CH}$ & $15-80 \mathrm{~km}$ & - & - & - & - \\
$\mathrm{NO}$ & $10-130 \mathrm{~km}$ & - & - & - & - \\
Temperature $^{\mathrm{a}}$ & $15-80 \mathrm{~km}$ & $0-60 \mathrm{~km}$ & $0-60 \mathrm{~km}$ & $1-70 \mathrm{~km}$ & $1-60 \mathrm{~km}$ \\
\hline
\end{tabular}

a only measured for ozonesondes; for other sources it is extracted from reanalyses.

channels. The latest available version is Version 6 which covers the period October 1993 to November 1996. Measurements were made between $55^{\circ}$ and $71^{\circ} \mathrm{N}$ and between $63^{\circ}$ and $88^{\circ} \mathrm{S}$ with a vertical resolution of $\sim 1 \mathrm{~km}$. The profiles of the different measured species cover an altitude range from $10 \mathrm{~km}$ to $50 \mathrm{~km}$ (see Table 3). For a more detailed description of the POAM II instrument and the retrievals see Glaccum et al. (1996) and Lumpe et al. (1997), respectively.

POAM III was launched after the satellite on which POAM II was located failed. It started measurements in April 1998 and ended in November 2005. Version 4 is the latest available dataset for POAM III. In this version, quality flags for the profiles of $\mathrm{O}_{3}, \mathrm{H}_{2} \mathrm{O}$ and $\mathrm{NO}_{2}$ were included to allow screening of lower quality measurements resulting from sunspot activity and aerosol artifacts (Lumpe et al., 2006). Beside these additions, POAM III data sets contain the same species as POAM II, with the measuring channels for the aerosol extinctions slightly shifted (see Table 1 ). The vertical resolution is also $\sim 1 \mathrm{~km}$ (Randall et al., 2003), and the measurements were made in almost identical latitude bands (from $54^{\circ}-71^{\circ} \mathrm{N}$ and $62^{\circ}-88^{\circ} \mathrm{S}$ ). The altitude range is slightly bigger for POAM III than for POAM II (see Table 3). For a more detailed description of the POAM III instrument and its retrieval algorithms see Lucke et al. (1999) and Lumpe et al. (2002), respectively.

Since temperature and pressure are not directly measured with the POAM instruments, both variables are taken from reanalyses either from the UK Met Office (UKMO) or the National Centers for Environmental Prediction (NCEP) and are included in the database. For sorting POAM II and POAM III in Grid II (latitude/pressure) and Grid III (equivalent latitude/potential temperature), the pressure and temperature values from NCEP were used. A sunrise/sunset identifier is also included in each measurement set. Error values are available for both POAM II and POAM III from the original data files and could therefore be added to the database.

\subsection{Ozonesonde data}

\subsubsection{Ozonesonde data selection}

Ozonesondes are balloon-borne instruments that measure in situ ozone with a wet-chemical method: ambient air is pumped through an electrolytic cell containing a buffered potassium iodide solution where ozone oxidises the iodide into iodine. The resultant current within the cell is directly proportional to the ozone concentration in the cell. There are several different ozonesonde types in use globally, with the most common being the electrochemical concentration cell (ECC) (Komhyr, 1969), the Brewer-Mast (BM) bubbler (Brewer and Milford, 1960) and the carbon-iodine (CI) sonde (Komhyr, 1965). All ozonesondes are flown together with a radiosonde to measure pressure, temperature and relative humidity.

Many studies analysing the suitability of ozonesonde measurements for long-term ozone trend detection have been published (Tiao et al., 1986; Bodeker et al., 1998; Logan et al., 1999). Although the quality of the ozonesonde data depends on the sonde preparation (Smit et al., 2007), the experience of the measuring team and some sources of error particular to each instrument, the measurement uncertainties are generally small and can be quantified. The ozonesonde measurements are also the only data included in this version of the BDBP that provide coverage in the troposphere. The ozonesonde data were subjected to thorough quality checks (described below) before being added to the BDBP.

Seven different sources for ozonesonde data were used for the database:

1. WOUDC Data DVD "Ozone Data for the world, ODW DVD\#1, 1926-2005”,

2. WOUDC database webpage for the most recent data not provided on the DVD (http://www.woudc.org/data_e. html), 
3. NOAA webpage, mainly for data from US stations (ftp: //ftp.cmdl.noaa.gov/ozwv/ozone/),

4. NDACC webpage, for stations that submit data only to the NDACC or for stations that submit data to both but in a more timely fashion to the NDACC (http://www. ndsc.ncep.noaa.gov/data/).

5. SHADOZ webpage, for equatorial stations not submitting their data to the WOUDC (http://croc.gsfc.nasa. gov/shadoz/).

6. Directly from the Lauder archive of ozonesonde flights,

7. Private communications with H. Claude from Hohenpeissenberg and R. Kivi from Sodankyla to get source profiles from those stations.

In total, profiles from 136 stations were added to the BDBP spanning $82^{\circ} \mathrm{N}$ to $90^{\circ} \mathrm{S}$ (see Appendix-Table A1). As long as the sonde type was detailed in the original data file, that sounding was rated as a potential candidate to be added to the database after passing several quality checks which are described below. Soundings from the following sonde types were accepted: Brewer-Mast, Brewer-GDR (Ronnebeck and Sonntag, 1976), ECC, Carbon-Iodine, Indian (Shreedharan, 1968) and Regener. Where the altitude and/or time after launch was not available in the original data file, or when the values were unrealistic (e.g. a time after launch of $3 \mathrm{~h}$ for the first data level), these were (re)calculated from the pressure and temperature measurements assuming a mean ascent rate of $6 \mathrm{~m} / \mathrm{s}$.

Normalization factors (NFs) are calculated by dividing a total column ozone value derived from the ozonesonde ozone profile by an independent total column ozone measurement available either from a coincident ground-based (Dobson or Brewer spectrophotometer) or satellite-based column ozone measurement. For the ozonesonde flights added to the BDBP, new NFs were calculated as follow. First the ozone column from the surface to the top of the ozonesonde flight was calculated using trapezoidal integration. Then the missing ozone between the top of the flight and the top of the atmosphere was added using the climatology of McPeters et al. (2007). Added together these provide the total column ozone estimate from the ozonesonde flight. The independent total column ozone value was extracted from the NIWA combined total column ozone database (Müller et al., 2008) according to the date, time and location of the ozonesonde flight. Because this combined total column ozone database is available only from November 1978 onwards, new NFs could not be calculated for flights prior to that date. For flights not reaching $30 \mathrm{hPa}$ the uncertainty on the partial column above the top of the flight is large and a reliable new NF could not be calculated. Therefore flights not reaching $30 \mathrm{hPa}$ were rejected. Both the original NFs listed in the data files (if available), and the new NFs, are considered for quality checks. If both NFs are available, the original NF must be between 0.9 and 1.1 and the new NF must be between 0.8 and 1.2. If only one NF is available then only the check appropriate for that $\mathrm{NF}$ is performed. If neither NF is available the profile is not added to the BDBP.

Each ozonesonde measurement set includes the original $\mathrm{NF}$, or the new NF if the original is not available, so that users of the ozonesonde data in the BDBP can choose whether or not to apply the NF to the ozone measurements. While the NF is stored in the BDBP it was not applied to the ozonesonde data. If NF were applied to the ozone soundings in the original data files they were de-applied before the ozone measurements were added to the BDBP.

Since the measurements in the BDBP are stored at specific altitude/pressure/theta levels, the values for those levels extracted from the ozonesonde profiles must be interpolated. For an interpolated value to be added to the database at least one measurement must be within $200 \mathrm{~m}$ of the respective level.

The period for which data are available differs from station to station. Flights started in the early 1960s at a few stations distributed globally. At many stations flights were done just for a few years, while other stations have measurements only during some months or during campaigns, and some stations have a continuous time series of ozone profiles up until the present. In the late 1990s, new ozonesonde stations were chosen to cover regions poorly represented at that time, specifically over the equator and southern hemisphere (Thompson et al., 2003). Combining all 7 mentioned ozonesonde data sources, flights from the early 1960s to 2006 were added to the BDBP as long as profiles were available and of suitable quality.

\subsubsection{Ozonesonde data errors}

The ozonesonde data files obtained through the sources detailed above for the most part do not include the measurement errors associated with each measurement, neither for ozone, temperature, relative humidity nor pressure. To estimate the error on the ozone measurement, information about sonde type quality and measurement errors were obtained from Smit and Kley (1996) unless otherwise specified (see below). According to their suggested classification of sonde type and altitude range different ozone error values were applied (see Fig. 2). In addition:

- ECC ozonesondes: error values were taken from Komhyr et al. (1985). For Lauder the error profiles for ECC ozonesondes of the $4 \mathrm{~A}$ and $5 \mathrm{~A}$ series described by Bodeker et al. (1998) were applied.

- Regener ozonesondes: those sondes were not tested in the analysis of Smit and Kley (1996), but it is known that the errors of those sondes tend to be quite high (WMO, 1989), so relatively high error values, commen- 
surate with other ozonesonde types with high errors, were assumed.

Error values for temperature, pressure and relative humidity for the soundings were set as follows:

- Temperature: error values for the sonde temperature measurements are set according to Bodeker et al. (1998). Different error values for unshaded and shaded temperature sensors are prescribed. For most soundings information about the shading of the temperature sensor is not available (the exception being Lauder) so error values for unshaded sensors are used.

- Pressure: depending on the station, different pressure error values are assumed. Since more detailed information about the soundings at Lauder are available, the pressure error value for that station was calculated from a large data set of calibrated pressure sensors and found to be $0.258 \mathrm{hPa}$. For all other stations error values were assumed to be $\sim 1 \mathrm{hPa}$ up to a height of $100 \mathrm{hPa}$, and $\sim 0.5 \mathrm{hPa}$ from a measurement height higher than $100 \mathrm{hPa}$, according to personal communication with Vaisala about pressure errors for radiosonde measurements. Uncertainties in temperature and pressure will be translated into errors in geopotential height and therefore add to the ozone uncertainty. This additional source of uncertainty in ozone has not been included. The same is true for all other data sources.

- Relative humidity: for all stations and all altitudes an error value of $3 \%$ for the relative humidity measurement was assumed, according to personal communication with Vaisala about humidity errors for radiosonde measurements.

It is not always Vaisala radiosondes that are flown with each ozonesonde at every station. According to SPARC (1998) before the early 1990s the most commonly used radiosonde in Europe and North America was the VIZ radiosonde. The accuracy of this radiosonde depends strongly on emissions in the IR (F. J. Schmidlin, personal communication, 2008) and lays withing the range errors for unshaded temperature sensors given by Bodeker et al. (1998). However, since Vaisala radiosondes are the most commonly used sondes and since the type of radiosonde used is seldom logged in the original ozonesonde data files, for all sonde data added to the BDBP the error values for pressure and relative humidity are set to the Vaisala radiosonde errors.

\subsubsection{Quality check}

In addition to the error checks described above, several further checks were made to screen and remove poor quality data from the ozonesonde data files, viz.:

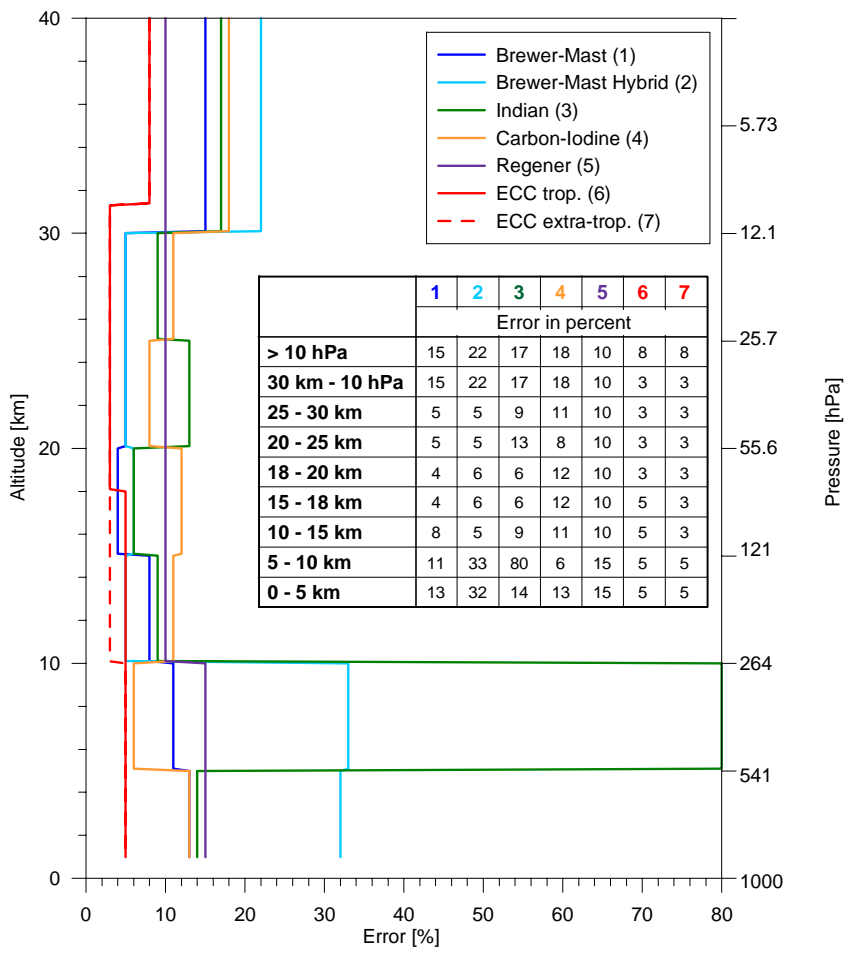

Fig. 2. Ozone errors [\%] for 6 different ozonesonde types and different altitude/pressure regions as included in the BDBP. Values are obtained from Smit and Kley (1996), or Komhyr et al. (1985).

- Individual ozone records are rejected when negative ozone partial pressures, $0.0 \mathrm{mPa}$ ozone partial pressures within $60^{\circ}$ of the equator, or ozone partial pressure $\geq 25 \mathrm{mPa}$ at altitudes above $30 \mathrm{hPa}$ are measured.

- Entire ozone profiles are rejected when unrealistically low ozone values over the whole profile (profile mean $<2 \mathrm{mPa}$ and profile maximum $<4 \mathrm{mPa}$ ) are found or when more than $33 \%$ of all ozone values in the profile are $0.0 \mathrm{mPa}$.

- Individual temperature records are rejected when values in the troposphere $>60^{\circ} \mathrm{C}$ or in the case of extreme spikes in stratospheric temperature (for one or two consecutive values). The spikes were defined in two different ways according to the resolution of the checked profile. Profiles with more than 10 values per kilometre were categorised as "high-resolution" profiles. For those the mean temperature and standard deviation for every km-layer was calculated and data values were rejected if they exceeded the range of mean temperature \pm 30 standard deviations. Temperature spikes for "low-resolution" profiles were defined by exceeding a maximum lapse rate. In the troposphere data values were rejected if the lapse rate was higher 


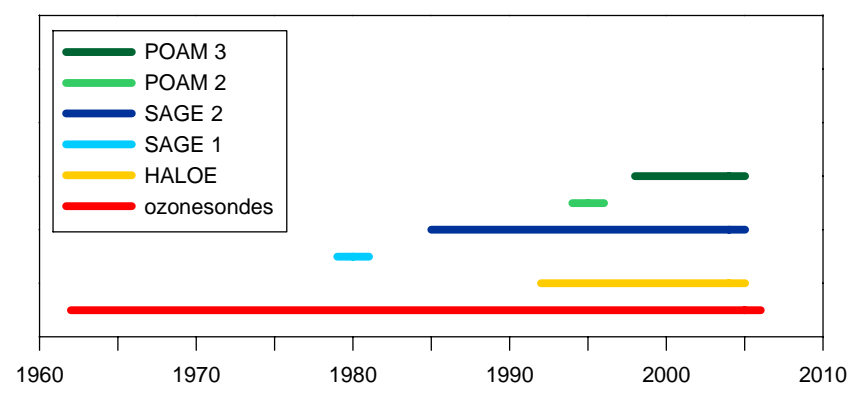

Fig. 3. Temporal coverage of the database. The red line represents the time period which is covered by ozonesonde data, the yellow line represents the coverage by HALOE etc.

than $0.06 \mathrm{~K} / \mathrm{m}$, for the stratosphere the maximum lapse rate was lowered slightly to $0.04 \mathrm{~K} / \mathrm{m}$.

- When two identical records at the same pressure/altitude level (not defined as ascending and descending values) are found, one is rejected.

No relative humidity values above the tropopause (as assumed for the application of the error values - see above) were added to the database since errors in humidity measurements from radiosondes are known to increase with decreasing water vapour content, temperature and pressure (Elliott and Gaffen, 1991). Stratospheric humidity data from radiosondes are therefore thought to be of no big use (SPARC, 2000). Although Miloshevich et al. (2001) worked out a correction for relative humidity measurements for Vaisala RS80A radiosondes, no further quality improvements were performed to the sonde humidity data in the database since in most cases the radiosonde type was not known.

\section{Database temporal, latitudinal and longitudinal cov- erage}

By combining measurements from several satellite-based instruments and from ozonesondes it is possible to achieve high temporal and spatial coverage in the BDBP. Table 2 summarises the temporal coverage of the satellites and these, together with the ozonesondes, are shown graphically in Fig. 3. Note that although the ozonesonde data cover a long time period, the spatial coverage can be poor due to the number and location of the ozonesonde stations. In this version of the BDBP, for 2006, only ozonesonde data are available, and so the spatial coverage for 2006 is poorer than for the preceding years.

To quantify the spatial and temporal coverage of the BDBP for a given altitude-/pressure-/isentropic level, we have defined factors (hereafter referred to as B-factors) that combine the temporal and spatial coverage into one value. For a given

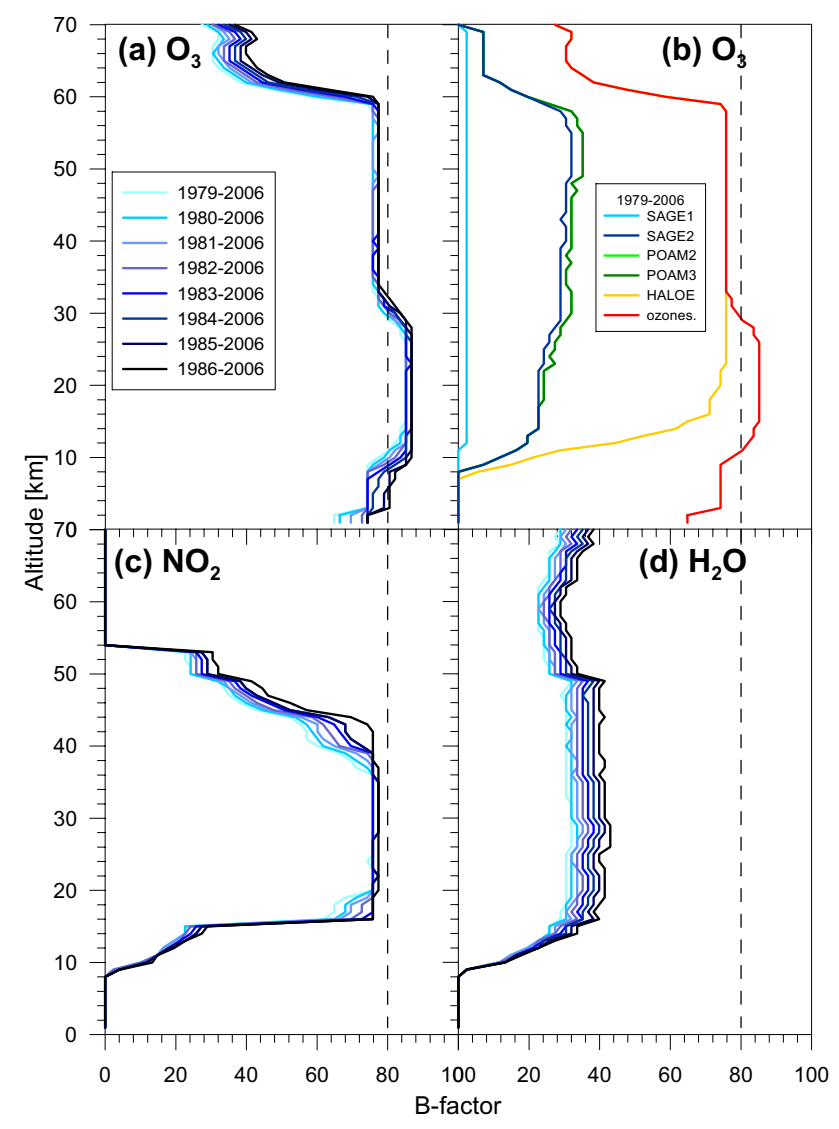

Fig. 4. B-factors for $\mathrm{O}_{3}, \mathrm{NO}_{2}$ and $\mathrm{H}_{2} \mathrm{O}$ as a function of changing time period (panels a, c and d respectively) and for $\mathrm{O}_{3}$ as a function of accumulated data sources (panel b). The $80 \%$ level in all panels is shown for reference.

level, a spatial grid is selected (e.g. $2^{\circ}$ latitude by $5^{\circ}$ longitude) and monthly means within each grid cell are calculated (described further in Sect. 5) over some selected time period. For the monthly mean to be valid at least 6 data points in each grid cell were required. A B-factor of $\mathrm{N} \%$ means that at least $\mathrm{N} \%$ of the grid cells have a monthly mean for at least $\mathrm{N} \%$ of the months in the selected time period. The B-Factor does not indicate which part of the globe is not sampled nor which periods within the total period are not covered. Figure 4 shows B-factors for a resolution of $2^{\circ}$ latitude by $5^{\circ}$ longitude for $\mathrm{O}_{3}$ as a function of changing time period (panel a) and changing data source (panel b) as well as $\mathrm{NO}_{2}$ and $\mathrm{H}_{2} \mathrm{O}$ for changing time period (panels $\mathrm{c}$ and $\mathrm{d}$ respectively).

As mentioned earlier, one selection criteria for the BDBP data sources was the goal of high temporal and spatial coverage for ozone. It can be seen in Fig. 4 that ozone has the highest B-factors for all three shown species, exceeding $80 \%$ between $\sim 10 \mathrm{~km}$ and $\sim 30 \mathrm{~km}$ even at a high resolution of $2^{\circ}$ by $5^{\circ}$. For $\mathrm{O}_{3}$, the periods with a late start year have higher Bfactors as a result of sparser coverage early in the period (see 
Fig. 3). B-factors for temperature are even slightly higher than those for $\mathrm{O}_{3}$ but are not shown here. Above $60 \mathrm{~km}$ coverage of ozone decreases rapidly.

In panel (b) of Fig. 4 the effects of the cumulative addition of different data sources on the temporal and spatial coverage of the BDBP are shown. First the effects of adding SAGE I data are shown, followed, in order, by SAGE II, POAM II, POAM III, HALOE and finally ozonesondes. Even though the addition of POAM III data extends the temporal coverage of the BDBP, the B-factors do not change with the addition of the POAM III data because it does not extend the spatial coverage. Clearly, at a resolution of $2^{\circ}$ by $5^{\circ}$, the inclusion of the ozonesondes is vital to achieve B-factors above $80 \%$ in the stratosphere and any coverage at all in the lower troposphere.

$\mathrm{NO}_{2}$ coverage does not reach the $80 \%$ mark although it is close in the altitude range $\sim 15 \mathrm{~km}$ to $\sim 45 \mathrm{~km}$ (see Fig. 4 panel c). Only very sparse data are available at altitude levels above $\sim 45 \mathrm{~km}$ and below $\sim 15 \mathrm{~km}$.

Of the 3 species shown, $\mathrm{H}_{2} \mathrm{O}$ is the only one with almost constant B-factors throughout the stratosphere and lower mesosphere (Fig. 4 panel d), from $\sim 15 \mathrm{~km}$ up to $70 \mathrm{~km}$. While relative humidity from the ozonesonde flights is added to the BDBP in the troposphere, these measurements are excluded from panel (d) of Fig. 4 since only water vapour measurements are considered. However, B-factors are significantly lower (maximum at around 40\%) than for the other species caused by the low number of satellite instruments that were added to the BDBP providing $\mathrm{H}_{2} \mathrm{O}$ data (see Table 3).

\section{Comparison with Randel and Wu database}

An often used and well established database for ozone trend analyses and calculations of changes in radiative forcing by ozone is that from Randel and Wu (2007), hereafter referred to as R\&W. In this section, monthly means of ozone at selected altitudes and latitudes calculated from the BDBP are compared with R\&W. As mentioned in Sect. 1, R\&W consists of monthly mean zonal mean ozone and is based mainly on SAGE I and SAGE II data, with ozonesonde profiles from Syowa and Resolute providing high latitude coverage.

Figure 5 compares monthly mean times series from the BDBP and R\&W at the equator and $25 \mathrm{~km}$ altitude. The monthly means for the BDBP and for SAGE I+SAGE II were calculated over the same $10^{\circ}$ latitude band and $1 \mathrm{~km}$ layer as in $\mathrm{R} \& \mathrm{~W}$, but with the requirement that there had to be at least 6 values available at the given latitude and altitude for the monthly mean to be valid. For both the BDBP and SAGE I+SAGE II, of the individual values available for the calculation of the monthly means, the highest and lowest $25 \%$ were discarded to ensure that extreme values were not included. This rather simple method of rejecting extreme values is sufficient for this exercise; more sophisticated meth-
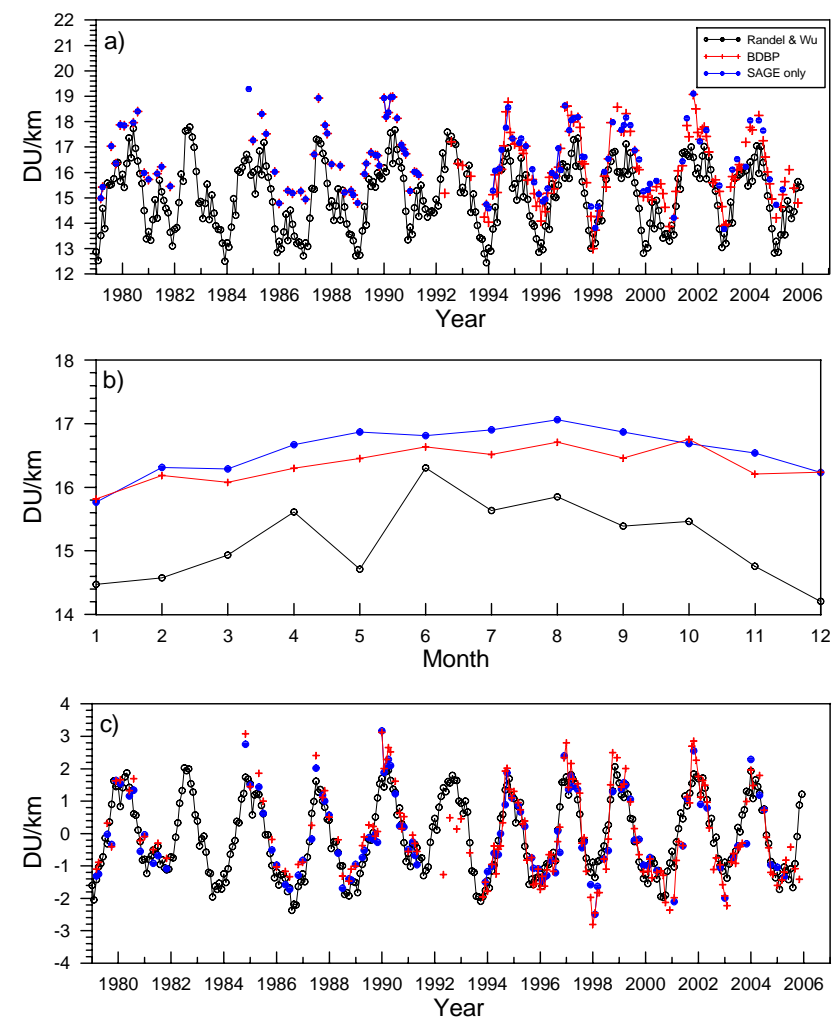

Fig. 5. (a) Monthly mean ozone number density (in DU/km) at the equator and $25 \mathrm{~km}$ from the BDBP (red crosses with lines joining adjacent values) and from $\mathrm{R} \& \mathrm{~W}$ (black open circles with lines joining adjacent values). To investigate the effects of adding data to the BDBP in addition to SAGE I and SAGE II, monthly means calculated from SAGE I and SAGE II only are also shown (blue dots with lines joining adjacent values). (b) A comparison of the mean annual cycles calculated from the monthly means plotted in panel (a) where $\mathrm{R} \& \mathrm{~W}$ values were excluded when BDBP values were not available to avoid any temporal biasing. (c) The monthly mean ozone anomaly times series calculated by subtracting the mean annual cycles plotted in panel (b) from the time series plotted in panel (a).

ods are in development for a 3-D (latitude, altitude, time) monthly mean ozone database that will be created from the BDBP.

Even though R\&W are based on SAGE I and SAGE II only in this part of the atmosphere, there are no missing values since the values provided by $R \& W$ are not the raw monthly means, but the values from a regression model fit to the raw monthly means (W. Randel, personal communication, 2007). Also apparent in panel (a) of Fig. 5 is an offset between BDBP and R\&W with BDBP monthly means being higher. The source of this offset is highlighted in panel (b); R\&W add monthly mean anomalies to the climatology of Fortuin and Kelder (1998) whereas the BDBP simply provides the original means of the raw data. If the anomaly time 

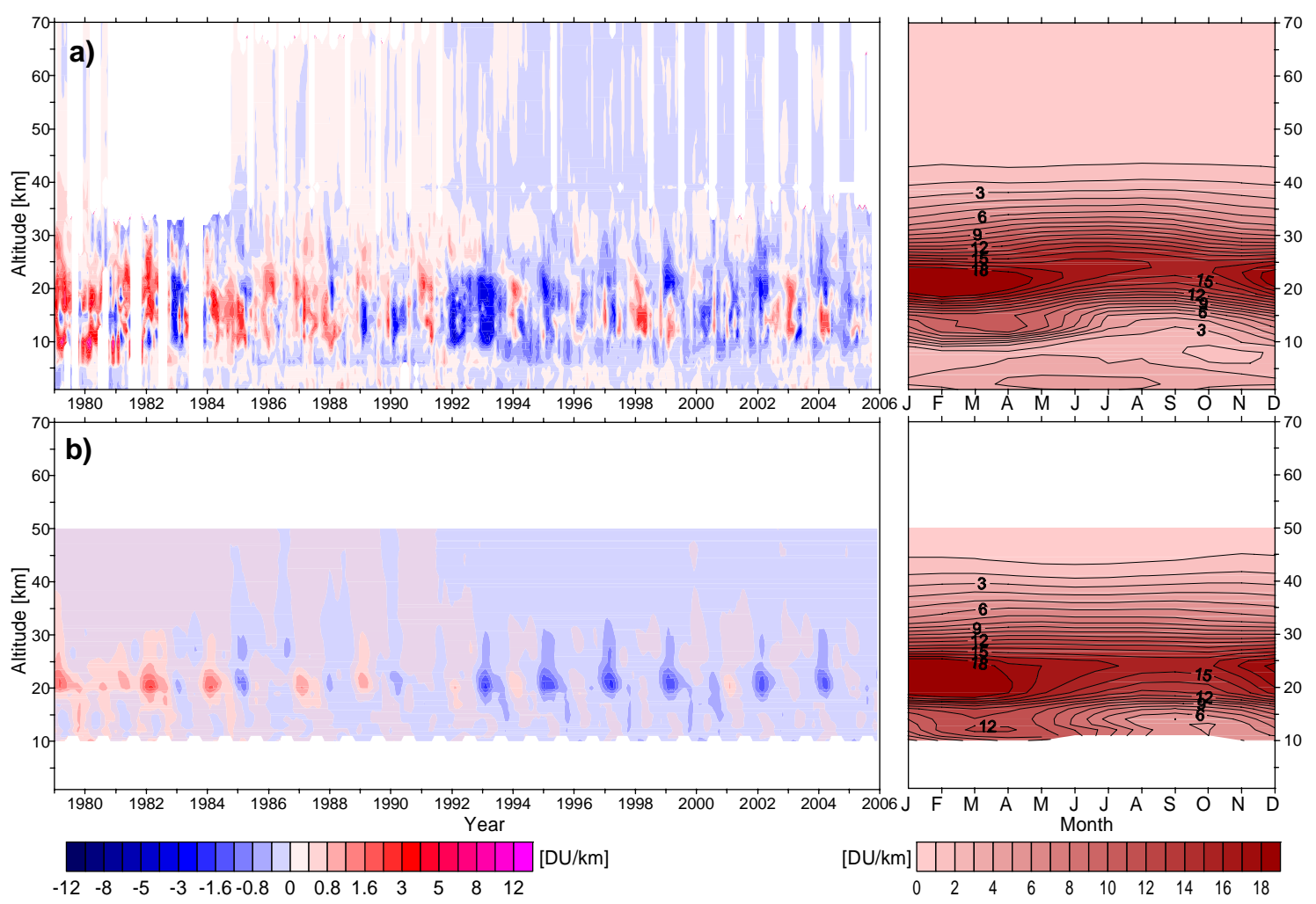

Fig. 6. (a) Ozone anomalies (left) and mean annual cycle (right) for data extracted from the BDBP, for altitudes between $1 \mathrm{~km}$ and $70 \mathrm{~km}$ and for the latitude zone from $40^{\circ} \mathrm{N}$ to $50^{\circ} \mathrm{N}$. (b) same as (a), for data extracted from $\mathrm{R} \& \mathrm{~W}$. White areas indicate where no values are available.

series alone are compared (panel c of Fig. 5) it is clear that the agreement between the BDBP and R\&W is excellent. It is also clear that $\mathrm{R} \& \mathrm{~W}$ does not capture some of the outliers in the BDBP (e.g. November 1984) because R\&W is the regression model fit and not the raw monthly mean data.

Figure 6 shows another comparison between the BDBP and $\mathrm{R} \& \mathrm{~W}$ where ozone anomalies were calculated by subtracting the mean annual cycle from monthly mean time series, for altitudes between $1 \mathrm{~km}$ and $70 \mathrm{~km}$ and for the latitude zone from $40^{\circ} \mathrm{N}$ to $50^{\circ} \mathrm{N}$.

The mean annual cycles (right hand panels in Fig. 6) compare well. The BDBP covers a greater altitude range than $\mathrm{R} \& \mathrm{~W}$ providing data between 50 and $70 \mathrm{~km}$ and, more importantly, good coverage in the troposphere. With a latitude band of $10^{\circ}$ the number of missing monthly means calculated using the BDBP is small; the gap in the earlier 1980s above $\sim 33 \mathrm{~km}$ is between SAGE I and SAGE II (ozonesondes provide data at lower altitudes). Anomalies (left hand panels in Fig. 6) of the same sign are found during similar periods and at similar altitudes. However, the BDBP anomalies have greater vertical scale, extending down to $\sim 10 \mathrm{~km}$ altitude whereas those of $\mathrm{R} \& \mathrm{~W}$ are suppressed below $20 \mathrm{~km}$. The anomalies calculated using the BDBP show greater temporal variability and larger amplitudes than $\mathrm{R} \& \mathrm{~W}$. This is be- cause $\mathrm{R} \& \mathrm{~W}$ is based on regression model output and regression models cannot capture all of the variability. Because the regression model used by $\mathrm{R} \& \mathrm{~W}$ does not include a basis function to describe the effects of volcanic eruptions on ozone, negative ozone anomalies in the lower stratosphere related to the Pinatubo eruption in the early 1990s are significantly more apparent in the BDBP than in R\&W. There is a discontinuity in the BDBP anomalies at $\sim 5 \mathrm{~km}$ altitude. This is an artifact of the monthly mean calculations using the BDBP where satellite data are not available for the monthly means at one altitude but are at the next higher altitude. Data from all of the added satellite instruments (see Sect. 3) have large error values in the troposphere for all measured species due to the tropospheric aerosol loading. It is suggested in various studies not to use these data for quantitative analyses (see for example Kar et al., 2002). For the purposes of this preliminary comparison with $\mathrm{R} \& \mathrm{~W}$, the approach used to calculate the monthly means is adequate. However, for a more accurate monthly mean database, weighting of the measurements used in each mean with their errors should be incorporated. 


\section{Summary and Outlook}

The material presented above outlines the construction of a new global database of trace gases and aerosols from multiple sources of high vertical resolution measurements. The first version of this database, referred to as BDBP version 1.0, includes measurements from several solar occultation satellite instruments (SAGE I and II, POAM II and III, HALOE) and from ozonesonde flights from over 130 stations globally, covering the period 1962 to 2006. It is planned to update the database annually to include the newest ozonesonde data, add historical data sources that have not yet been included (e.g. ILAS and GOMOS, and more ground-based measurements, for example lidar data), add measurements from new satellite-based instruments currently in development, and possibly newer versions of the data already in the database (e.g. from the application of improved satellite retrieval algorithms).

The internal construction of the database allows for considerable flexibility:

- Where measurements are available at high temporal resolution e.g. during an intensive ozonesonde campaign, the resolution of the original data is maintained.

- Measurement sets can include any number of individual measurements taken by the same instrument at that latitude, longitude, altitude and time and this can vary between data sources or within a data source.

- The database has a single common format so that utilities to extract subsets of data from the BDBP are easy to write and quick to execute.

- The database consist of three different grids but the structure of the measurement sets is the same for all three grids which simplifies data handling.

- The construction of the database allows for new, as yet undefined, species, or measurements from new instruments, to be added without revision of the existing database - the measurement sets from the new instruments, possibly including newly defined species, are interleaved amongst the existing measurement sets.

- Measurement sets for a latitude and altitude are sorted by time which speeds up navigation and searching within the BDBP.

- Although the original trace gas profiles are not included in the BDBP as one coherent unit but are stored on predefined levels, profiles can easily be extracted from the $\mathrm{BDBP}$, if required, since the vertical resolution is high (about $1 \mathrm{~km}$ for Grid I and Grid II).

This flexibility allows for multiple applications:

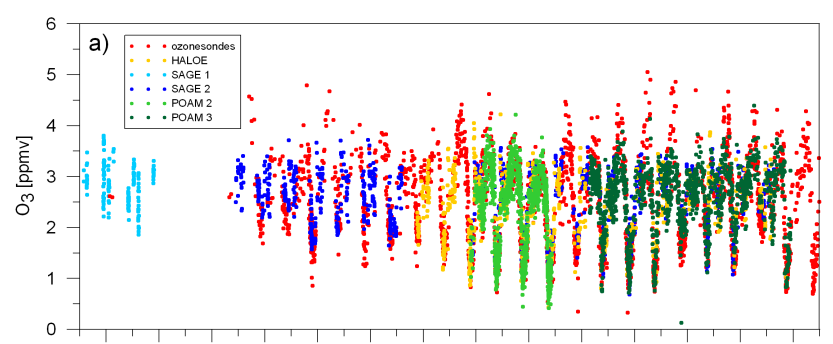

19801982198419861988199019921994199619982000200220042006

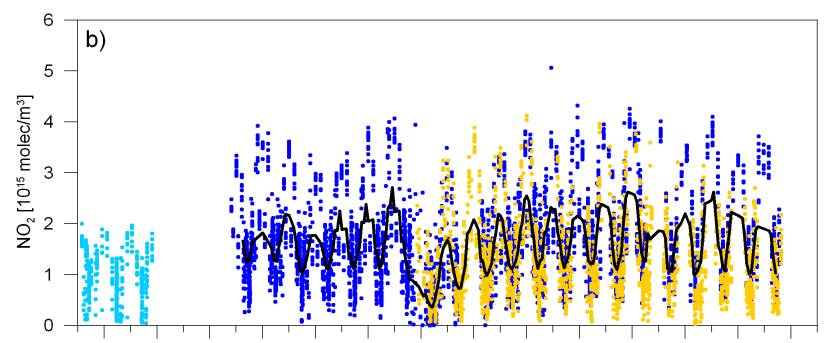

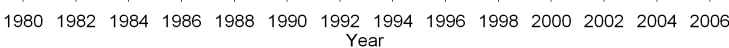

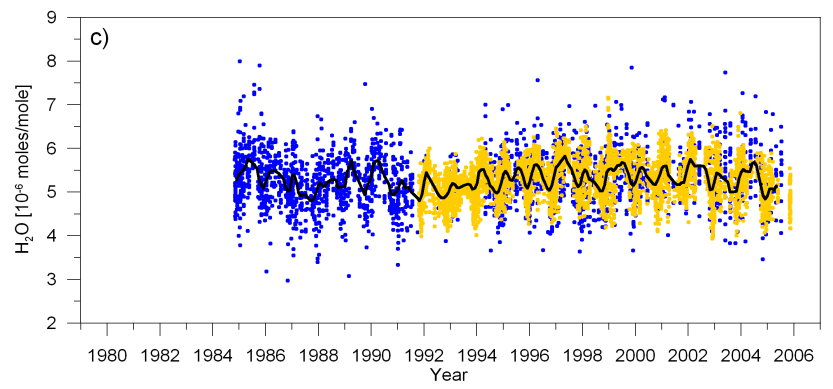

Fig. 7. Individual data values extracted from the database for three different species. The different data sources are colour coded. (a) Ozone (in ppmv) at the $550 \mathrm{~K}$ isentropic level for equivalent latitudes south of $70^{\circ} \mathrm{S}$ extracted from Grid III. For clarity only every 5th data point of SAGE II, HALOE, POAM II and POAM III is plotted. (b) $\mathrm{NO}_{2}$ (in $10^{15} \mathrm{molec} / \mathrm{m}^{3}$ ) at $25 \mathrm{~km}$ altitude between $44^{\circ} \mathrm{S}$ and $46^{\circ} \mathrm{S}$ extracted from Grid I. The thick black line represents the 3-month running mean for the monthly means calculated from all data points. (c) $\mathrm{H}_{2} \mathrm{O}$ (in $10^{-6}$ moles/mole) between $9 \mathrm{hPa}$ and $7 \mathrm{hPa}$ for the latitude band $30-40^{\circ} \mathrm{N}$ extracted from Grid II. For clarity only every 5 th data point from SAGE II and HALOE is plotted. The thick black line represents the 3-month running mean for the monthly means calculated from all data points.

- Because temporal means are not calculated, trace gas profiles at a specific location and time, if available, can be extracted for studies requiring point source data.

- Case studies with data from only one data source, or a combination of data sources, can be made.

- Since a longitude value is stored with each measurement set, analyses requiring longitudinal disaggregation can be undertaken. 
- The temporal and spatial coverage of the BDBP is sufficient to provide data for statistically significant trend analyses.

- It is possible to bin the data from the BDBP in several different spatial and temporal resolutions, as required for analyses (e.g. monthly means, seasonal means, yearly means etc.), since data in the BDBP are stored with the information of the exact measurement time, latitude and longitude.

- The combination of data sources in the BDBP provides a robust basis for climatology calculations which can be used to validate chemistry-climate models.

- Since the BDBP covers a long time period, climatologies calculated from the BDBP can be used to provide boundary conditions for model simulations.

Examples of some of the products available through the BDBP are shown in Fig. 7.

The evolution of the ozone hole every spring is clearly visible and the values from the 6 different data sources show no significant offsets or drifts in comparison to each other. The $\mathrm{NO}_{2}$ time series plotted in panel (b) of Fig. 7 shows decreases in $\mathrm{NO}_{2}$ in 1991 and 1992 resulting from the Mt. Pinatubo eruption. The $\mathrm{H}_{2} \mathrm{O}$ time series plotted in panel (c) of Fig. 7 shows good agreement between the HALOE and SAGE II data sources and the derived monthly means are in good agreement with Fig. 3a of Rosenlof et al. (2001). In contrast to the high water vapour values seen in the 19911994 SAGE II data in Fig. 3a of Rosenlof et al. (2001), the SAGE II data screening implemented here removes most of the $\mathrm{H}_{2} \mathrm{O}$ data points in this period where measurements were strongly affected by the eruption of Mt. Pinatubo.

This version of the BDBP does not consider problems of inhomogeneities between the different data sources. While comprehensive screening was applied to the different data sources, systematic offsets and drifts between the data sources are likely (McPeters, 1999; Randall et al., 2003; Nazaryan et al., 2005). To correct for these offsets and drifts we are developing procedures for deriving correction functions that can be applied as a function of latitude, altitude and time. The way we are doing this is to first select a "gold standard" dataset. In this case we will select SAGE II. We will then iteratively compare the other data sources against the gold standard. Differences between coincident measurements from the selected data source and the gold standard will be calculated. Functions for latitude zones, including second order polynomial dependence in the vertical and offset and trend in time, will be fitted to the differences. The functions will then be temporarily applied to correct the data which will then be merged with the gold standard to produce a new extended gold standard. In this way we can sequentially derive correction functions for each data source. The correction functions will not be applied to the data in the BDBP but will be provided with each data source so that the users of the database can apply these functions should they wish. This functionality will be included in Version 2 of the BDBP.

An advantage of combining measurements from multiple sources is the improved temporal and spatial coverage achieved. It was shown that only with the combination of the different data sources a high index of coverage (B-factor) could be achieved. Especially the ozonesonde data contribute considerably to the coverage of the troposphere and the lower stratosphere.

One of the first applications of the BDBP will be the creation of a global latitude/altitude/time monthly mean ozone database to provide the ozone boundary conditions for global climate model simulations. To achieve this, missing values need to be spatially and/or temporally interpolated and is the focus of ongoing development. 
Table A1. Ozonesonde stations from which ozone profiles have been added to the BDBP. Note that for some stations only seasonal data are available although it is not specified in the table. The number of soundings per year is the average value (rounded to the next full number) of all years where soundings were available and before quality selection criteria were applied.

\begin{tabular}{|c|c|c|c|c|c|}
\hline Station name & Latitude & Longitude & Time period & $\begin{array}{l}\text { Num. of sound. } \\
\text { per year (ave.) }\end{array}$ & Data sources \\
\hline Alert & 82.49 & -62.42 & $1987-2005$ & 50 & WOUDC \\
\hline Eureka/Eureka Lab & 80.04 & -86.17 & $1992-2006$ & 61 & WOUDC \\
\hline Ny Alesund & 78.93 & 11.88 & 1990-2006 & 100 & WOUDC \\
\hline Thule & 76.53 & -68.74 & 1991-2005 & 18 & WOUDC \& NDACC \\
\hline Resolute & 74.72 & -94.98 & 1966-2005 & 39 & WOUDC \\
\hline Summit & 72.60 & -38.50 & 2005-2006 & 21 & NOAA \\
\hline Barrow & 71.31 & -156.60 & 1974 & 4 & WOUDC \\
\hline Scoresbysund & 70.50 & -22.00 & $1989,1991-2005$ & 47 & WOUDC \& NDACC \\
\hline Sodankyla & 67.33 & 26.50 & 1988-2006 & 69 & $\begin{array}{l}\text { WOUDC \& NDACC \& } \\
\text { personal communication }\end{array}$ \\
\hline Salekhard & 66.70 & 66.70 & 2005 & 18 & NDACC \\
\hline Poker Flat & 65.13 & -147.45 & 1979-1982 & 13 & WOUDC \\
\hline Fairbanks & 64.81 & -147.86 & 1965 & 26 & WOUDC \\
\hline Iqaluit & 63.75 & -68.55 & 1991-1992 & 16 & WOUDC \\
\hline Yakutsk & 62.03 & 129.63 & 2004-2005 & 9 & NDACC \\
\hline Jokioinen & 60.81 & 23.50 & 1995-1998 & 25 & WOUDC \\
\hline Lerwick & 60.13 & -1.18 & 1992-2001 & 55 & WOUDC \\
\hline Churchill & 58.75 & -94.07 & 1973-2006 & 40 & WOUDC \\
\hline Cold Lake & 54.78 & -110.05 & $1977-1981$ & 16 & WOUDC \\
\hline Edmonton & 53.55 & -114.10 & $1970,1972-2005$ & 42 & WOUDC \\
\hline Goose Bay & 53.30 & -60.36 & 1963, 1969-2006 & 45 & WOUDC \\
\hline Berlin/Tempelhof & 52.46 & 13.43 & 1966-1973 & 45 & WOUDC \\
\hline Legionowo & 52.40 & 20.96 & 1979-2006 & 49 & WOUDC \\
\hline Aberystwyth & 52.40 & -4.10 & 1991-2001 & 36 & NDACC \\
\hline Lindenberg & 52.21 & 14.12 & 1975-2006 & 63 & WOUDC \\
\hline Vanscoy & 52.11 & -107.16 & 1992, 2000, 2002, 2004 & 10 & WOUDC \\
\hline Debilt & 52.10 & 5.18 & 1992-2006 & 42 & WOUDC \& NDACC \\
\hline Valentia Observ. & 51.93 & -10.25 & 1994-2004 & 28 & WOUDC \\
\hline Yorkton & 51.26 & -102.46 & 1975-1978 & 24 & WOUDC \\
\hline Uccle & 50.80 & 4.35 & 1965-1967, 1969-2005 & 105 & WOUDC \& NDACC \\
\hline Gimli & 50.63 & -97.05 & 1980, 1982-1983, 1985 & 9 & WOUDC \\
\hline Bratts Lake (Regina) & 50.20 & -104.70 & 2003-2006 & 44 & WOUDC \\
\hline Praha & 50.02 & 14.45 & 1979-2006 & 42 & WOUDC \\
\hline Kelowna & 49.92 & -119.40 & 2003-2006 & 41 & WOUDC \\
\hline Hohenpeissenberg & 47.80 & 11.02 & 1966-2006 & 105 & personal communication \\
\hline Spokane & 47.66 & -117.41 & 1976 & 7 & WOUDC \\
\hline Great Falls & 47.48 & -111.35 & 1977 & 4 & WOUDC \\
\hline Caribou & 46.86 & -68.03 & 1981 & 1 & WOUDC \\
\hline Thalwil & 46.81 & 8.45 & $1966-1968$ & 61 & WOUDC \\
\hline Payerne & 46.49 & 6.57 & $1968,1970-2006$ & 119 & WOUDC \\
\hline Pellston & 45.56 & -84.68 & 2004 & 38 & NOAA \\
\hline S.Pietro Capofiume & 44.65 & 11.61 & $1984,1991-1993$ & 25 & WOUDC \\
\hline Biscarrosse/SMS & 44.36 & -1.23 & 1976-1983 & 45 & WOUDC \\
\hline Egbert & 44.23 & -79.78 & 2003-2006 & 37 & WOUDC \\
\hline Haute Provence & 43.93 & 5.70 & $1981,1995-2006$ & 45 & WOUDC \& NDACC \\
\hline Sable Island & 43.93 & -60.10 & 1997 & 31 & NOAA \\
\hline Yarmouth & 43.87 & -66.10 & 2003-2006 & 31 & WOUDC \\
\hline Toronto & 43.78 & -79.47 & $\begin{array}{l}1976,1978,1980 \\
1982,1987,1994\end{array}$ & 3 & WOUDC \\
\hline Sapporo & 43.06 & 141.33 & $1969-2006$ & 26 & WOUDC \\
\hline Sofia & 42.81 & 23.38 & 1982-1991 & 24 & WOUDC \\
\hline
\end{tabular}


Table A1. Continued.

\begin{tabular}{|c|c|c|c|c|c|}
\hline Station name & Latitude & Longitude & Time period & $\begin{array}{l}\text { Num. of sound. } \\
\text { per year (ave.) }\end{array}$ & Data sources \\
\hline Ainsworth (Airport) & 42.58 & -100.00 & 1986 & 8 & WOUDC \\
\hline Bedford & 42.45 & -71.26 & $1969-1971$ & 26 & WOUDC \\
\hline Rhode Island & 41.40 & -71.50 & 2004-2006 & 59 & NOAA \\
\hline Trinidad Head & 40.80 & -124.16 & 1999-2001 & 36 & WOUDC \\
\hline Purdue University & 40.50 & -87.00 & 1996 & 27 & NOAA \\
\hline Madrid/Barajas & 40.46 & -3.65 & 1994-2002, 2004-2006 & 34 & WOUDC \\
\hline Boulder & 40.08 & -105.25 & $\begin{array}{l}\text { 1963-1966, 1979-1989, } \\
1991-2006\end{array}$ & 22 & $\begin{array}{l}\text { WOUDC \& NOAA \& } \\
\text { NDACC }\end{array}$ \\
\hline Ankara & 39.95 & 32.88 & 1994-2001 & 21 & WOUDC \\
\hline Denver & 39.76 & -104.88 & 1977 & 1 & WOUDC \\
\hline Cagliari & 39.25 & 9.05 & $1968-1970,1972-1980$ & 35 & WOUDC \\
\hline Topeka & 39.06 & -95.63 & 1963 & 10 & WOUDC \\
\hline Sterling & 38.98 & -77.48 & $1962-1966$ & 33 & WOUDC \\
\hline Virginia & 38.10 & -78.50 & 1996 & 31 & NOAA \\
\hline Wallops Island & 37.89 & -75.48 & 1970-1982, 1984-2006 & 44 & WOUDC \& NDACC \\
\hline El Arenosillo & 37.10 & -6.73 & 1983 & 17 & WOUDC \\
\hline Nashville & 36.25 & -86.65 & 1995,1999 & 21 & NOAA \\
\hline Tateno & 36.06 & 140.10 & 1968-2006 & 32 & WOUDC \\
\hline Huntsville & 35.28 & -86.58 & 1999-2003 & 33 & WOUDC \\
\hline Cheju & 33.50 & 126.50 & 2001 & 13 & WOUDC \\
\hline Long View & 32.50 & -94.75 & 1976 & 3 & WOUDC \\
\hline Isfahan & 32.47 & 51.42 & 1995-1996, 1999-2005 & 11 & WOUDC \\
\hline San Diego & 32.45 & -117.11 & 1977 & 2 & WOUDC \\
\hline Palestine & 31.80 & -95.71 & $1975-1985$ & 19 & WOUDC \\
\hline Kagoshima & 31.58 & 130.56 & 1969-2005 & 23 & WOUDC \\
\hline McDonald Observ. & 30.66 & -90.93 & 1969 & 7 & WOUDC \\
\hline Houston & 29.94 & -95.54 & 2000 & 26 & NOAA \\
\hline New Delhi & 28.65 & 77.21 & $\begin{array}{l}1969,1971-1976, \\
1983-1986,1994-2003\end{array}$ & 10 & WOUDC \\
\hline Izana & 28.48 & -16.26 & 1995-2006 & 59 & WOUDC \& NDACC \\
\hline Naha & 26.20 & 127.68 & 1989-2006 & 37 & WOUDC \\
\hline Taipei & 25.02 & 121.47 & $2000-2001$ & 32 & WOUDC \\
\hline Hong Kong Observ. & 22.31 & 114.17 & 2000-2006 & 38 & WOUDC \\
\hline Poona & 18.53 & 73.85 & $\begin{array}{l}\text { 1966, 1968-1976, 1982-1986, } \\
\text { 1994-2000, 2002-2003 }\end{array}$ & 8 & WOUDC \\
\hline San Juan & 18.48 & -66.13 & 1976 & 6 & WOUDC \\
\hline Coolidge Field & 17.28 & -61.78 & 1976 & 7 & WOUDC \\
\hline Hilo & 19.70 & -155.06 & 1964-1965, 1982-1997, 1999-2006 & 42 & WOUDC \& NDACC \\
\hline Heredia & 10.00 & -84.11 & $2005-2006$ & 65 & WOUDC \& SHADOZ \\
\hline Ft. Sherman & 9.33 & 79.98 & 1977 & 45 & WOUDC \\
\hline Albrook & 8.98 & -79.55 & 1980 & 34 & WOUDC \\
\hline Thivandrum & 8.48 & 76.95 & $\begin{array}{l}\text { 1969, 1973-1976, 1983-1986, } \\
\text { 1994-2000, 2002-2003 }\end{array}$ & 12 & WOUDC \\
\hline Cotonou & 6.21 & 2.23 & 2005-2006 & 46 & SHADOZ \\
\hline Paramaribo & 5.81 & -55.21 & 1999-2006 & 43 & WOUDC \& NDACC \\
\hline Kourou & 5.33 & -52.65 & 1974 & 6 & WOUDC \\
\hline Kaashidhoo & 5.00 & 73.50 & 1999 & 55 & WOUDC \& NOAA \\
\hline Sepang Airport & 2.73 & 101.70 & $1998-2006$ & 26 & WOUDC \\
\hline Christmas Island & 2.01 & -157.40 & 1999 & 4 & SHADOZ \\
\hline San Cristobal & -0.92 & -89.60 & 1998-2006 & 34 & WOUDC \& SHADOZ \\
\hline Nairobi & -1.26 & 36.80 & 1996-2006 & 43 & WOUDC \& SHADOZ \\
\hline Canton Island & -2.76 & -171.70 & 1965 & 31 & WOUDC \\
\hline Malindi & -2.99 & 40.19 & 1999-2006 & 13 & WOUDC \& SHADOZ \\
\hline Brazzaville & -4.28 & 15.25 & 1990-1992 & 27 & WOUDC \\
\hline
\end{tabular}


Table A1. Continued.

\begin{tabular}{|c|c|c|c|c|c|}
\hline Station name & Latitude & Longitude & Time period & $\begin{array}{l}\text { Num. of sound. } \\
\text { per year (ave.) }\end{array}$ & Data sources \\
\hline Maxaranguape & -5.44 & -35.33 & 2002-2006 & 30 & WOUDC \\
\hline Natal & -5.84 & -35.21 & $\begin{array}{l}\text { 1979-1982, 1990-1992, } \\
1997-2006\end{array}$ & 29 & WOUDC \& NDACC \\
\hline Watukosek (Java) & -7.57 & 112.65 & 1998-2006 & 30 & WOUDC \\
\hline Ascension Island & -7.98 & -14.42 & $\begin{array}{l}1990-1992,1997-2003, \\
2005\end{array}$ & 44 & WOUDC \\
\hline Porto Nacional & -10.80 & -48.40 & 1992 & 16 & WOUDC \\
\hline Chilca & -12.50 & -76.80 & 1975 & 5 & WOUDC \\
\hline Samoa & $-1-4.25$ & -170.56 & 1995-2006 & 37 & WOUDC \\
\hline Lusaka & -15.42 & 28.32 & 2000 & 9 & SHADOZ \\
\hline Cuiaba & -15.60 & -56.10 & 1992 & 22 & WOUDC \\
\hline Ovejuyo & -16.51 & -68.03 & 1965 & 10 & WOUDC \\
\hline Papeete (Tahiti) & -18.00 & -149.00 & 1995-1999 & 30 & WOUDC \& NOAA \\
\hline Suva (Fiji) & -18.13 & 178.31 & 1997-2005 & 28 & WOUDC \& SHADOZ \\
\hline Etosha Pan & -19.20 & 15.90 & 1992 & 16 & WOUDC \\
\hline La Reunion Island & -21.07 & 55.48 & 1998-2006 & 30 & WOUDC \& SHADOZ \\
\hline Irene & -25.91 & 28.21 & 1990-1993, 1998-2006 & 27 & WOUDC \\
\hline Easter Island & -27.17 & -109.42 & 1995-1997 & 25 & WOUDC \\
\hline Broadmeadows & -37.69 & 144.94 & 1999-2003 & 44 & WOUDC \\
\hline Laverton & -37.86 & 144.75 & 1982-1999 & 24 & WOUDC \\
\hline Aspendale & -38.03 & 145.10 & $1965-1982$ & 42 & WOUDC \\
\hline Puerto Montt & -41.45 & -72.83 & 1964-1965 & 4 & WOUDC \\
\hline Christchurch & -43.48 & 172.55 & 1965 & 25 & WOUDC \\
\hline Lauder & -45.038 & 169.684 & $1986-2006$ & 63 & Lauder archive \\
\hline Macquarie Island & -54.50 & 158.96 & 1994, 1996-2003 & 38 & WOUDC \\
\hline Marambio & -64.23 & -56.71 & 1988-1998,2006 & 29 & WOUDC \\
\hline Wilkes & -66.25 & 110.51 & 1963 & 6 & WOUDC \\
\hline Dumont d'Urville & -66.41 & 140.01 & 1991-2006 & 26 & NDACC \\
\hline Davis & -68.57 & 77.97 & $2003-2005$ & 20 & WOUDC \\
\hline Syowa & -69.00 & 39.58 & $\begin{array}{l}\text { 1966-1975, 1977-1984, } \\
1986-2006\end{array}$ & 32 & WOUDC \\
\hline Maitri & -70.46 & 11.45 & 1994-1998 & 19 & WOUDC \\
\hline Neumayer & -70.65 & -8.25 & 1992-2006 & 75 & WOUDC \\
\hline Georg Forster Station & -70.77 & 11.83 & 1985-1992 & 49 & personal communication \\
\hline Hallett & -72.31 & 170.21 & $1962-1963$ & 13 & WOUDC \\
\hline McMurdo & -77.85 & 166.67 & 1986-2005 & 35 & NDACC \\
\hline Byrd & -80.03 & -119.51 & 1963-1966 & 28 & WOUDC \\
\hline Amundsen-Scott & -89.98 & -24.80 & $\begin{array}{l}\text { 1962, 1964-1971, } \\
\text { 1986-1987, 1991-2006 }\end{array}$ & 50 & WOUDC \& NDACC \\
\hline Ship 1 & - & - & 1965-1966 & 11 & WOUDC \\
\hline Ship 3 & - & - & 1999 & 25 & WOUDC \\
\hline
\end{tabular}


Acknowledgements. We thank all institutions and colleagues who provided us with data for the database: NASA, NRL, WOUDC, NOAA, NDACC, SHADOZ, H. Claude, R. Kivi, P. van der Gathen, L. W. Thomason and all the people involved in the measurements and processing of the data. We also want to thank R. Schofield for the valuable advice on the SAGE II data screening details, L. W. Thomason for the suggestions about the SAGE I data screening method, W.J. Randel and F. Wu for access to their database, as well as W. J. Randel for answering patiently all our questions concerning the $\mathrm{R} \& \mathrm{~W}$ database. We appreciate very much the comments and suggestions from J. Logan about the ozonesonde quality screening. B. Hassler's work was funded by a DAAD studentship.

Edited by: F. J. Dentener

\section{References}

Bhatt, P. P., Remsberg, E. E., Gordley, L. L., McInerney, J. M., Brackett, V. G., and Russell III, J. M.: An evaluation of the quality of Halogen Occultation Experiment ozone profiles in the lower stratosphere, J. Geophys. Res., 104(D08), 9261-9275, 1999.

Bodeker, G. E., Boyd, I. S., and Matthews, W. A.: Trends and variability in vertical ozone and temperature profiles measured by ozonesondes at Lauder, New Zealand: 1986-1996, J. Geophys. Res., 103(D22), 28661-28681, 1998.

Brewer, A. W. and Milford, J. R.: The Oxford-Kew Ozone sonde, Proc. R. Soc. London, A256, 470-495, 1960.

Butchart, N. and Remsberg, E. E.: The area of the stratospheric polar vortex as a diagnostic for tracer transport on an isentropic surface, J. Atmos. Sci., 43, 1319-1339, 1986.

Cunnold, D. M., Chu, W. P., Barnes, R. A., McCormick, M. P., and Veiga, R. E.: Validation of SAGE II Ozone Measurements, J. Geophys. Res., 94(D06), 8447-8460, 1989.

Elliott, W. P., and Gaffen, D. J.: On the utility of radiosonde humidity archives for climate studies, Bull. Amer. Meteorol. Soc., 72, 1507-1520, 1991.

Forster, P. M. D. F. and Shine, K. P.: Radiative forcing and temperature trends from stratospheric ozone changes, J. Geophys. Res., 102, 10 841-10 855, 1997.

Fortuin, J. P. and Kelder, H.: An ozone climatology based on ozonesonde and satellite measurements, J. Geophys. Res., 103(D24), 31 709-31 734, 1998.

Glaccum, W., Lucke, R., Bevilacqua, R. M., Shettle, E. P., Hornstein, J. S., Chen, D. T., Lumpe, J. D., Krigman, S. S., Debrestian, D. J., Fromm, M. D., Dalaudier, F., Chassefiere, E., Deniel, C., Randall, C. E., Rusch, D. W., Olivero, J. J., Brogniez, C., Lenoble, J., and Kremer, R.: The Polar Ozone and Aerosol Measurement (POAM II) Instrument, J. Geophys. Res., 101(D9), 14 479-14 487, 1996.

Hervig, M. and McHugh, M.: Cirrus detection using HALOE measurements, Geophys. Res. Lett., 26(6), 719-722, 1999.

Kar, J., Trepte, C. R., Thomason, L. W., Zawodny, J. M., Cunnold, D. M., and Wang, H.-J.: On the tropospheric measurements of ozone by the Stratospheric Aerosol and Gas Experiment II (SAGE II, version 6.1) in the tropics, Geophys. Res. Lett., 29(24), 2208, doi:10.1029/2002GL016241, 2002.

Kistler, R., Kalnay, E., Collins, W., Saha, S., White, G., Woollen, J., Chelliah, M., Ebisuzaki, W., Kanamitsu, M., Kousky, V., van den
Dool, H., Jenne, R., and Fiorino, M.: The NCEPNCAR 50Year Reanalysis: Monthly Means CDROM and Documentation, Bull. Am. Soc., 82(2), 247-267, 2001.

Komhyr, W. D.: A carbon-iodine sonde sensor for atmospheric soundings, Proc. Ozone Symp., Albuquerque, p. 26, Geneva, 1965.

Komhyr, W. D.: Electrochemical concentration cells for gas analysis, Ann. Geophys., 25, 2003-210, 1969,

http://www.ann-geophys.net/25/2003/1969/.

Komhyr, W. D., Oltmans, S. J., Chopra, A. N., and Franchois, P. R.: Performance characteristics of high-altitude ECC ozonsondes, in: Atmospheric Ozone, Proceedings of the Quadrennial Ozone Symposium, Greece, 1985.

Liu, X., Chance, K., Sioris, C. E., Kurosu, T. P., and Newchurch, M. J.: Intercomparison of GOME, ozonesonde, and SAGE II measurements of ozone: Demonstration of the need to homogenize available ozonesonde data sets, J. Geophys. Res., 111, D14305, doi:10.1029/2005JD006718, 2006.

Logan, J. A., Megretskaia, I. A., Miller, A. J., Tiao, G. C., Choi, D., Zhang, L., Stolarski, R. S., Labow, G. J., Hollandsworth, S. M., Bodeker, G. E., Claude, H., DeMuer, D., Kerr, J. B., Tarasick, D. W., Oltmans, S. J., Johnson, B., Schmidlin, F., Staehelin, J., Viatte, P. and Uchino, O.: Trends in the vertical distribution of ozone: a comparison of two analyses of ozonesonde data, J. Geophys. Res., 104, 26373-26399, 1999.

Lucke, R. L., Korwan, D., Bevilacqua, R. M., Hornstein, J. S., Shettle, E. P., Chen, D. T., Daehler, M., Lumpe, J. D., Fromm, M. D., Debrestian, D., Neff, B., Squire, M., König-Langlo, G., and Davies, J.: The Polar Ozone and Aerosol Measurement (POAM III) Instrument and Early Validation Results, J. Geophys. Res., 104(D15), 18 785-18 799, 1999.

Lumpe, J. D., Bevilacqua, R. M., Hoppel, K. W., Krigman, S. S., Kriebel, D. L., Randall, C. E., Rusch, D. W., Brogniez, C., Ramananaherosa, R., Shettle, E. P., Olivero, J. J., Lenoble, J., and Pruvost, P.: POAM II Retrieval Algorithm and Error Analysis, J. Geophys. Res., 102(D19), 23 593-23 614, 1997.

Lumpe, J. D., Bevilacqua, R. M., Hoppel, K. W., and Randall, C. E.: POAM III Retrieval Algorithm and Error Analysis, J. Geophys. Res., 107(D21), 4575, doi:10.1029/2002JD002137, 2002.

Lumpe, J., Bevilacqua, R., Randall, C., Nedoluha, G., Hoppel, K., Russel, J., Harvey, V. L., Schiller, C., Sen, B., Taha, G., Toon, G., and Vömel, H.: Validation of Polar Ozone and Aerosol Measurement (POAM) III version 4 stratospheric water vapor, J. Geophys. Res., 111, D11301, doi:10.1029/2005JD006763, 2006.

McCormick, M. P., Zawodny, J. M., Veiga, R. E., Larsen, J. C., and Wang, P. H.: An overview of SAGE I and SAGE II ozone measurements, Planet. Space Sci., 37(12), 1567-1586, 1989.

McKenna, D. S., Grooß, J.-U., Günther, G., Konopka, P., Müller, R., Carver, G., and Sasano, Y.: A new Chemical Lagrangian Model of the Stratosphere (CLaMS) 2. Formulation of chemistry scheme and initialization, J. Geophys. Res., 107(D15), 4256, doi:10.1029/2000JD000113, 2002.

McPeters, R. D., Hofmann, D. J., Clark, M., Flynn, L., Froidevaux, L., Gross, M., Johnson, B., Koenig, G., Liu, X., McDermid, S., McGee, T., Murcray, F., Newchurch, M. J., Oltmans, S. J., Parrish, A., Schnell, R., Singh, U., Tsou, J. J., Walsh, T., and Zawodny, J. M.: Results from the 1995 Stratospheric Ozone Profile Intercomparison at Mauna Loa, J. Geophys. Res., 104(D23), 30 505-30 514, 1999. 
McPeters, R. D., Lebow, G. J., and Logan, J. A.: Ozone climatological profiles for satellite retrieval algorithms, J. Geophys. Res., 112, D05308, doi:10.1029/2005JD006823, 2007.

Miloshevich, L. M., Vömel, H., Paukkunen, A., Heymsfield, A. J., and Oltmans, S. J.: Characterization and correction of relative humidity measurements from Vaisala RS80-A radiosondes at cold temperatures, J. Atmos. Oceanic Technol., 18, 135-156, 2001.

Müller, R., Grooß, J.-U., Lemmen, K., Heinze, D., Dameris, M., and Bodeker, G. E.: Simple measures of ozone depletion in the polar stratosphere, Atmos. Chem. Phys., 8, 251-264, 2008, http://www.atmos-chem-phys.net/8/251/2008/.

Nash, E. R., Newman, P. A., Rosenfield, J. E., and Schoeberl, M. R.: An objective determination of the polar vortex using Ertel's potential vorticity, J. Geophys. Res., 101(D5), 9471-9478, 1996.

Nazaryan, H. and McCormick, M. P.: Comparisons of Stratospheric Aerosol and Gas Experiment (SAGE II) and Solar Backscatter Ultraviolet Instrument (SBUV/2) ozone profiles and trend estimates, J. Geophys. Res., 110, D17302, doi:10.1029/2004JD005483, 2005.

Nazaryan, H., McCormick, M. P., and Russell III, J. M.: New studies of SAGE II and HALOE ozone profile and longterm change comparisons, J. Geophys. Res., 110, D09305, doi:10.1029/2004JD005425, 2005.

Randall, C. E., Rusch, D. W., Bevilacqua, R. M., Hoppel, K. W., Lumpe, J. D., Shettle, E., Thompson, E., Deaver, L., Zawodny, J., Kyrö, E., Johnson, B., Kelder, H., Dorokhov, V. M., KönigLanglo, G., and Gil, M.: Validation of POAM III ozone: Comparisons with ozonesonde and satellite data, J. Geophys. Res., 108(D12), 4367, doi:10.1029/2002JD002944, 2003.

Randel, W. J. and Wu, F.: A stratospheric ozone profile data set for 19792005: Variability, trends, and comparisons with column ozone data, J. Geophys. Res., 112, D06313, doi:10.1029/2006JD007339, 2007.

Remsberg, E. E. and Deaver, L. E.: Interannual, solar cycle, and trend terms in middle atmospheric temperature time series from HALOE, J. Geophys. Res., 110, D06106, doi:10.1029/2004JD004905, 2005.

Rind, D., Lerner, J., and Zawodny, J.: A complementary analysis for SAGE II data profiles, Geophys. Res. Lett., 32, L07812, doi:10.1029/2005GL022550, 2005.

Ronnebeck, K., and Sonntag, D.: Eine weiterentwickelte elektrochemische Ozonradiosonde, Z. Meteorol., 26, 15-19, 1976.

Rosenlof, K. H., Oltmans, S. J., Kley, D., Russell, J. M. III, Chiou, E.-W., Chu, W. P., Johnson, D. G., Kelly, K. K., Michelsen, H. A., Nedoluha, G. E., Remsberg, E. E., Toon, G. C., and McCormick, M. P.: Stratospheric water vapour increases over the past half-century, Geophys. Res. Lett., 28(7), 1195-1198, 2001.

Russell, J. M. III, Gordley, L. L., Park, J. H., Drayson, S. R., Hesketh, D. H., Cicerone, R. J., Tuck, A. F., Frederick, J. E., Harries, J. E., and Crutzen, P.: The Halogen Occultation Experiment, J. Geophys. Res., 98(D6), 10777-10 797, 1993.

Shreedharan, C. R.: An Indian electrochemical ozonesonde, J. Phys. E. Sci. Instrum. Sr-2, 995-997, 1968.

Smit, H. G. J. and Kley, D.: Jülich Ozone Sonde Intercomparison
Experiment (JOSIE), 5 February - 8 March 1996, WMO Report No. 130, 108 pp., 1996.

Smit, H. G. J., Straeter, W., Johnson, B. J., Oltmans, S. J., Davies, J., Tarasick, D. W., Hoegger, B., Stubi, R., Schmidlin, F. J., Northam, T., Thompson, A. M., Witte, J. C., Boyd, I., and Posny, F.: Assessment of the performance of ECC-ozonesondes under quasi-flight conditions in the environmental simulation chamber: Insights from the Juelich Ozone Sonde Intercomparison Experiment (JOSIE), J. Geophys. Res., 112, D19306, doi:10.1029/2006JD007308, 2007.

SPARC/IOC/GAW: Assessment of trends in the Vertical Distribution of Ozone, Chap. 1, World Climate Research Programme, Report No.1., WMO Ozone Research and Monitoring Project Report No. 43, 1998.

SPARC: Assessment of Upper Tropospheric and Stratospheric Water Vapour, Chap. 2, World Climate Research Programme, WCRP-113, WMP/TD-No.1043, 261-264, 2000.

Steil, B., Brühl, C., Manzini, E., Crutzen, P. J., Lelieveld, J., Rasch, P. J., Roeckner, E., and Krüger, K.: A new interactive chemistry-climate model: 1 . Present-day climatology and interannual variability of the middle atmosphere using the model and 9 years of HALOE/UARS data, J. Geophys. Res., 109(D9), 4290, doi:10.1029/2002JD002971, 2003.

Thompson, A. M., Witte, J. C., McPeters, R. D., Oltmans, S. J., Schmidlin, J. A., Logan, J. A., Fujiwara, M., Kirchhoff, V. W. J. H., Posny, F., Coetzee, G. J. R., Hoegger, B., Kawakami, S., Ogawa, T., Johnson, B. J., Vömel, H., and Labow, G.: Southern Hemisphere Additional Ozonesondes (SHADOZ) 1998-2000 tropical ozone climatology - 1. Comparison with Total Ozone Mapping Spectrometer (TOMS) and gound-based measurements, J. Geophys. Res., 108(D2), 8238, doi:10.1029/2001JD000967, 2003.

Tiao, G. C., Reinsel, G. C., Pedrick, J. H., Allenby, G. M., Mateer, C. L., Miller, A. J., and DeLuisi, J. J.: A statistical trend analysis of ozonesonde data, J. Geophys. Res., 91, 13 121-13 136, 1986.

Veiga, R. E., Cunnold, D. M., Chu, W. P., and McCormick, M. P.: Stratospheric aerosol and gas experiments I and II comparisons with ozonesondes, J. Geophys. Res., 100(D5), 9073-9090, 1995.

Wang, H. J., Cunnold, D. M., and Bao, X.: A critical analysis of Stratospheric Aerosol and Gas Experiment ozone trends, J. Geophys. Res., 101(D7), 12495-12514, 1996.

Wang, H. J., Cunnold, D. M., Thomason, L. W., Zawodny, J. M., and Bodeker, G. E.: Assessment of SAGE version 6.1 ozone data quality, J. Geophys. Res., 107(D23), 4691, doi:10.1029/2002JD002418, 2002.

Wang, P.-H., Cunnold, D. M., Trepte, C. R., Wang, H. J., Jing, P., Fishman, J., Brackett, V. G., Zawodny, J. M., and Bodeker, G. E.: Ozone variability in the midlatitude upper troposphere and lower stratosphere diagnosed from a monthly SAGE II climatology relative to the tropopause, J. Geophys. Res., 111, D21304, doi:10.1029/2005JD006108, 2006.

WMO (World Meteorological Organization): Scientific Assessment of Stratospheric Ozone: 1989, Vol. 1, Global Ozone Research and Monitoring Project - Report No. 50, 486 pp., Geneva, Switzerland, 1989. 